Wesleyan University

From the SelectedWorks of Giulio M Gallarotti

Spring 2000

The Advent of the Prosperous Society: The Rise of the Guardian State and Structural Change in the World Economy

Giulio M Gallarotti, Wesleyan University

Available at: https://works.bepress.com/giulio_gallarotti/18/ 


\title{
The Advent of the Prosperous Society: The Rise of the Guardian State and Structural Change in the World Economy*
}

\author{
Giulio M. Gallarotti
}

*The author is grateful to Richard Adelstein, William Barber, Helge Berger, Michaelle Biddle, Marc Eisner, Jeffry Frieden, Stanley Lebergott, Michael Lovell, Donald Moon, Peter Rutland, David Selover, Gil Skilman, and David Titus for advice and comments on earlier drafts, and to Michael Bordo and the Economic Cycle Research Institute at Columbia University for providing valuable data.

Review of International Political Economy, 7:1 (Spring) 2000, pp. 1-52

Erratum and Corrigendum Note: The author would like to note that an error was made in estimating the data for the structural stability tests in Table 11. The reader should therefore disregard these test results.

Copyright note: This is a pre-published draft of the article, as the Review of Political Economy does not allow published articles to be uploaded to databases. The published article is available at the issue listed above. 


\section{Introduction}

At the very end of The General Theory, Keynes underscored how much human economic behavior is driven by ideas. Even more than the theories of defunct economists, the economic landscape is in large part a product of the beliefs, ideas and general economic orientations of economic agents. This article argues that over the last century there has been a fundamental change in the economic orientation of industrially advanced democracies, and this has had a pervasive impact on both their macroeconomies and their international economic relations. Put more starkly, changing expectations about prosperity and the role of government as an economic guardian have fundamentally reshaped the economic geography of the world economy. In humorous tone, it might even be called a cowardly new world, one in which societies refuse to brave the vagaries of unrestrained markets. This argument presents an alternative to traditional explanations of economics processes in which scholars have studied changes very narrowly and have conceived of them as independent from one another. While countless studies have talked about the changes in individual macroeconomic processes as well as changes in the various international economic relations across the past century, few have looked at these processes in a unifying light. In other words, much has been said about the trees, but far less has been said about the forest. This article looks at these processes and relations as comprising "economic plates." According to the theory of plate tectonics, certain aggregations of the planet's surface occupy singular sub-structures which move according to underlying geologic conditions. While looking at these component parts individually is important in its own right, it is also important to understand how pervasive underlying forces shape the entire aggregate. So too in economics, economic processes and relations can be seen as occupying such plates themselves: i.e., phenomena that are fundamentally linked so that they can be influenced in toto. Macroeconomic processes and international economic relations do occupy the same fundamental plate, and the plate has made significant shifts over the past century as a result of strong underlying forces in the form of changing orientations regarding peoples' economic fates and governments' relation to the market.

Seven sections follow this introduction. Section II discusses the relation between ideas and political markets, and their joint impact on economic outcomes. Section III discusses the market society and the night watchman state that prevailed before World War I. Section IV explains how market society and the night watchman state eventually gave way to the prosperous society and guardian state in the $20^{\text {th }}$ century. Section V discusses the impact of the prosperous society and guardian state on national macroeconomies and government spending. Section VI discusses the international economic impact of these forces. Section VII provides concluding arguments. Section VIII provides a statistical appendix. 


\section{Ideologies, Political Markets, and Economic Outcomes}

All economic systems are in some important way endogenous: that is, economic relations are embedded in some greater constellation of social relations. ${ }^{1}$ Hence, understanding the nature of and changes in economic relations cannot be done in full measure by studying the economic outcomes in and of themselves alone. High growth may be as much a result of "a will to grow" than of technological shocks, human capital formation, or cyclical changes in inventories. While the proximate cause may be deficit spending, a high disposition toward growth (because a society's values are directed toward maintaining employment) may in fact be the catalyst for government spending. Such values may also throw economic outcomes into a more inflationary path. Economic outcomes are just one dimension of social outcomes, which in turn are driven by prevailing ideologies about what particular goals societies aspire to and/or the thought processes which condition behavior among the mass of economic actors in those societies. Within the greater study of social science, both sociologists and political scientists have elaborately discussed the link between ideas and economic actions. The idea of looking at the relationship between economics and ideas goes as far back as the Marxian link between prevailing class ideologies and the economic landscape. Sociologists such as Parsons and Smelser (1984) have explored this nexus as the integration of social and economic theory. Political scientists Krasner (1983) and Haas (1992) have talked about epistemic communities and regimes: i.e., actual outcomes are explained by rules or norms which decision makers and larger groups of individuals adhere to. Economists have explored the microeconomic foundations of macroeconomics by assessing the broader economic manifestations of decision-making under uncertainty, adaptive behavior, self-fulfilling forecasts, and rational expectations. ${ }^{2}$ In terms of economic outcomes, significant discussion of the link between ideologies and economics has come under the rubric of the cultural foundations of economic growth and development. ${ }^{3}$

Ideas, alone, however, are insufficient to determine economic outcomes. They require the help of politics. Ideas invariably impact on the operation of political markets, which themselves reinforce the influence of prevailing economic ideologies. While ideologies can carry autonomous influence, they must ultimately be politically reinforced if they are to significantly shape policy and, consequently, outcomes. If politicians do not face incentives to translate prevailing ideas into law or policy, then the ideas themselves will cast no institutional shadow and therefore have less of an impact on economic outcomes. Fundamentally, there must be no serious impediments to the supply of and demand for economic outcomes consistent with prevailing ideas. On the supply side, policymakers must be able to supply the kinds of policies that are demanded by society at large. Supply must be competitive (i.e., society should have a choice among potential suppliers, in other words a democratic supply of government output), otherwise

\footnotetext{
${ }^{1}$ As Polanyi (1957, p. 46) put it, "man's economy, as a rule, is submerged in his social relations." Ruggie (1983) has stressed how economic relations have a strong social dimension in that they are "embedded" in prevailing frameworks of social norms.

${ }^{2}$ On rational expectations, see Sheffrin (1996).

${ }^{3}$ For a good survey of the literature, see Harrison (1985).
} 
policies may be restricted. This does not mean the existence of perfect political markets, only that supply and demand for economic outcomes remain unimpaired. In fact, once supply and demand effects translate into some definitive electoral imperative regarding economic outcomes, we would expect the regime in power or coming into power to use the state's monopoly over policy to effect the desired outcomes. Obviously, democracy would appear to be the system of government most conducive to political markets that reinforce prevailing ideologies since such a system exhibits the fewest impediments to the smooth functioning of political demand and supply. ${ }^{4}$

The demanders of these economic outcomes will be organized groups. These groups may manifest their political activity as a class, some alliance of specific classes, or a more amorphous group (i.e., that has no visible class identity) that is animated by specific issues or goals. ${ }^{5}$ The policies may reflect complete victory by one group (e.g., the classical Marxist outcome of the dominant ideas in society being the ideas of the dominant class) or a compromise among competing groups. In this way the state apparatus (i.e., the institutional manifestations of these policy orientations) can serve specific functions in the service of political interest groups: to assure the primacy of the interests of one specific group, assure the primacy of the interests of an alliance of groups against other alliances or specific groups, or perform a harmonizing function for the political struggle by providing points of convergence for the major competing groups.

In sum, ideas and politics do not exist independently of one another. Rather than forming disparate processes that somehow converge to impact on policy styles and economic outcomes, the two represent a set of forces that are systematically linked, and prevailing policy styles and consequent economic outcomes are manifestations of this systematic relation.

\section{Market Society and the Night Watchman State: The 19th Century and the Classical Liberal Consensus}

Karl Polanyi, in The Great Transformation (1957, p. 250), called the $19^{\text {th }}$ century a "market society" with respect to prevailing economic ideologies of the time. The market society, for Polanyi, resulted from the intersection of two institutions that dominated the 19th century: the liberal state and a self-regulating market economy. The liberal state represented decision makers who were driven by principles of economic liberalism, and as a consequence supported the institutions necessary to maintain a market economy. This "conventional wisdom" of the $19^{\text {th }}$ century, as Galbraith $(1970, p$.

\footnotetext{
${ }^{4}$ This discussion of the impact of political markets highlights the main issues regarding the theory of the supply of and demand for government output. An ever-increasing literature has emerged on this subject since Downs' (1957) seminal work on the economic theory of politics. Good surveys are Mueller (1989 and 1997).

${ }^{5}$ Class-based theories of politics aver the primacy of the first two groups, while pluralist theories have looked at the influence of interest groups outside of a socio-economic context. On class-based theories, see especially Offe (1984), Rueschemeyer, et. al. (1992), Holloway and Picciotto (1978), Poggi (1990), Gough (1979), Jessop (1982 and 1990), and Przeworski (1986). For a good survey of the literature, see Barrow (1993). The pluralist literature is vast, for good surveys see Mueller (1989 and 1997).
} 
38) referred to it, was very much steeped in a classical and neoclassical vision of economics with respect to its faith in markets. As long as some level of competition could be maintained, the market was capable of providing sufficient wealth without systematic intervention by states. This reflected a deeper faith in the ability of supply and demand forces, working through a healthy price mechanism, to clear markets and restore equilibrium. Since there were no fundamental flaws in the competitive market mechanism, it was not something anybody needed to manage on a large scale. Instead, concerns were much more of a microeconomic nature. While the macroeconomy was self-sufficient and could autonomously produce desirable outcomes, it was not always the case that each component of the economy shared the same luxury. Sometimes specific sectors did not function efficiently, either because of a lack of competition or because of stochastic bottlenecks. In such cases there were pockets of allocative inefficiency that required tinkering. In other words, macroeconomic outcomes were neither targeted nor even conceived as a goal of policy, rather the emphasis was on preserving the foundations of a competitive economy. The economic role of the state that emerged in this period was consistent with this micro concern with the economy: like the night watchman, the state was in the business of preventing localized disturbances (e.g., antitrust) to the system, but not involved in ongoing management. ${ }^{6}$

If markets were capable of providing economic welfare, and markets were not seriously impaired, then the prevailing classical liberal consensus dictated a rather passive vision of macroeconomic outcomes. More precisely, the liberal ideology dictated a high level of tolerance of macroeconomic outcomes. Prices, employment, and growth were merely residual properties of a system over which there was no, and should not be, political control. Like the weather, certain inclement outcomes were to be accepted, with hope that fairer conditions (i.e., prosperity) would soon follow. As Hawtrey (1932, p. 300) put it, in $19^{\text {th }}$ century society "the trade cycle was accepted with a spirit of fatalism."

That such toleration existed meant that political markets for macroeconomic outcomes which provided prosperity were significantly underdeveloped. Essentially, this period was marked by a disjuncture between politics and economics, and this meant that no strong economic electoral imperative emerged. On the demand side, toleration dampened the demand for prosperity. This ideological toleration interacted with factors defining the level of democratic development in the industrially advanced world to restrain demand even more. Potential demanders of prosperity in the $19^{\text {th }}$ century were fewer. Groups (in this case economic classes) which bore the main economic burden of recession were not as politically empowered as they would become in the $20^{\text {th }}$ century. Labor parties were not strong in national legislatures, the political strength of unions was underdeveloped, and restricted suffrage meant that lower income groups especially burdened by poverty and recession did not yet have the power to convey their preferences. $^{\text {P }}$

\footnotetext{
${ }^{6}$ On the classical and neoclassical foundations of $19^{\text {th }}$ century liberalism and the consequent impact on state-economy relations, see Briggs (1968, p. 44), Alt and Crystal (1983, pp. 56-58), Galbraith (1970), Ruggie (1983, p. 389), Nurkse (1944, p. 213), and Buchanan and Wagner (1977, pp. 27,28)

${ }^{7}$ On the political underdevelopment of subordinate classes, see Rueschemeyer et. al., (1992), Therborn (1977), Przeworski and Sprague (1986), Alt and Crystal (1983), and Meltzer and Richard (1981).
} 
On the supply side, since politicians were very much part of their age ideologically, there was an autonomous incentive not to intervene in the macroeconomy to relieve the economic burdens of recession and poverty. But just as importantly, underdeveloped demand for prosperity meant that the political costs of recession, unemployment, and poverty were not preponderant. Hence, there was neither any endogenous motivation to supply prosperity.

The underdeveloped political market for prosperity meant that the state did not have to intervene heavily in the economy. Consequently, it was not necessary for the state to fully develop the political levers necessary to manage the macroeconomy (i.e., controlling the money supply and manipulating the budget). This had significant consequences for the state's relation to the macroeconomy. For one, there was no need to monopolize the money supply. Second, the budget was not heavily politicized.

In this period it would be generous to call the management of the money supply in the industrially developed world even semi-public. Central banks as a rule did not have monopoly over note issue and the political control over the operations of these banks was far underdeveloped compared to the $20^{\text {th }}$ century. Central banks had strong profit motives given that they were publicly owned and the shareholders had strong expectations in that direction. The private nature of central banking even reinforced an already existing hardmoney orthodoxy. Polanyi (1957, p. 24) notes how this period regarded "stable money as the supreme need of human society." In fact, monetary authorities tended to see depreciating currencies as a "national disgrace." That profit-oriented and responsible private banking would be conterminous with a stable money supply is fairly straightforward. In a regime in which the issue of notes was competitive, any bank issuing notes as a normal function of its private banking activities would absolutely have a strong incentive to refrain from issuing those notes in an inflationary manner. ${ }^{8}$ If notes could not be covered by sufficient specie, the result would be a flight from its notes which could endanger the bank's very solvency. Since all banks of issue (including central banks) were strongly compelled by the profit motive, there was a tendency toward a stable money supply. And this of course conformed to the prevailing monetary orthodoxy against inflation. ${ }^{9}$

Both the ideology of stable money and the private elements of central banking were allowed to persist because the anti-interventionist bias of prevailing political markets produced few incentives to control the money supply. Since policymakers did not pay a high price for failing to provide prosperity, it was not necessary for them to use their monopoly over state institutions to create levers by which to generate macroeconomic outcomes. In other words, states did not have to monopolize the money supply because they did not need to lubricate or even inflate the economy out of a

\footnotetext{
${ }^{8}$ In a metallist regime this would be synonymous with conformity between notes and underlying specie reserves.

${ }^{9}$ See Gallarotti (1995, pp. 114-119) on the structure of central banking in the $19^{\text {th }}$ century. On the hard money orthodoxy of this period, see Alt and Crystal (1983, p. 56) and Gallarotti (1995).
} 
recession in the short run. The political benefits of inflation were far fewer in the $19^{\text {th }}$ century. ${ }^{10}$

The government budget shared a similar fate during the $19^{\text {th }}$ century. Like inflation, government spending was also strongly configured by a prevailing orthodoxy, in this case one of fiscal prudence, and like inflation it was subject to a similar contingent rule. The rule was one of sound finance which could be violated in certain extraordinary circumstances like war, but in such a case peacetime surpluses would be targeted afterward so as to retire debt generated in war. Otherwise, fiscal orthodoxy in this period drew no distinction between public and private finance. Mueller (1989, p. 295) notes how running a peacetime deficit in the $19^{\text {th }}$ century was considered by the public as an "almost immoral act." One might say fiscal policy did not exist insofar as political discretion could be exercised over the budget. The budget, in peacetime, was run by fairly mechanistic rules oriented around the convergence of spending and revenues. This "Gladstonian" fiscal orientation, as Laidler (1987, p. 364) calls it, served to eliminate government spending as a lever with which to influence the macroeconomy. Hence, political control over the budget was at a minimum. This, as in the case of money, conformed to the prevailing ideology of the period. If macroeconomies didn't have to be inflated out of recession, than neither did they need to be "spent" out of recession. Moreover, since the state was not blamed for poverty, elaborate transfer programs directed toward social insurance and welfare did not need to come into being. ${ }^{11}$ Government, consequently, did not have to be very large because it didn't need the resources to engage in the management of aggregate demand to preserve full employment, nor did it have to construct an elaborate welfare structure to abate economic adversity and poverty. The market could provide both, government didn't have to. ${ }^{12}$

In sum, the $19^{\text {th }}$ century state did not have to manage the macroeconomy because policymakers were not being held accountable for recession, unemployment, and poverty. Such things were acts of nature, not people, and consequently out of the realm of control. In essence, the classical liberal consensus cast a strong shadow over the political institutions of the period. It set the foundations for how the state would relate to the economy. The role of a night watchman state was well configured for the economic demands which laissez-faire society placed on the state apparatus in this period. ${ }^{13}$ The

\footnotetext{
${ }^{10}$ This is not to say political manipulation of the money supply did not exist, only that it was directed toward other priorities. Avoiding inflation under a metallist regime was always seen as a contingent rule that could be broken under pressing political conditions, most commonly war. Hence, during war, convertibility was commonly suspended and inflationary issue of money engineered. See Bordo and Kydland (1990).

${ }^{11}$ On the prevailing fiscal orthodoxy in the $19^{\text {th }}$ century, see also Alt and Crystal (1983, p. 58), Peden (1990, pp. 211,212), Barro (1987), and Buchanan and Wagner (1977, pp. 11-21).

${ }^{12}$ Polanyi (1957, pp. 77-85) underscores the liberals' bias against building elaborate welfare systems in his discussion of how capitalists were against wage subsidies in the Poor and Speenhamland Laws because they saw them as destructive of workers' incentive.

${ }^{13}$ The less nationalist economic urge of the night watchman state vis-à-vis its successor of the $20^{\text {th }}$ century (guardian state) may seem paradoxical in light of the fact that the $19^{\text {th }}$ century produced a high-point in colonization, and wars of the period (unlike much of the conflict in the $20^{\text {th }}$ century) appeared more motivated by national interests than by ideology. This seeming paradox withers when one considers the relation between economic and security policy. In the $20^{\text {th }}$ century the two have merged (i.e., economic
} 
state hardly existed as an interventionist force, it never sought to construct political institutions that could serve as levers to control the macroeconomy, and therefore macroeconomic policy barely existed. ${ }^{14}$ All of this would change significantly in the $20^{\text {th }}$ century, as a new ideology of prosperity and new state apparatus (i.e., the guardian state) would arise to transform the political and economic landscape.

\section{The Causal Mechanism in the Historical Transition from Market Society to the Prosperous Society: Class Relations and Class Conflict in Modern Capitalism}

With the end of World War I there arose a new ideology about society and the economy. Polanyi (1957, p. 252) talked of the end of market society. Peoples' views about their economic fates altered fundamentally, from a passive toleration of macroeconomic outcomes, to one that insisted on achieving and maintaining some level of prosperity. Burns (1960, p. 1) nicely describes this new ideology of prosperity in citing the prevailing view regarding "the need for and the attainability of economic progress." The description becomes complete by adding that society was also "entitled" to such progress. The adversity of the market would no longer be tolerated, as the new ideology of prosperity sought to, in Galbraith's (1970, p. 39) terms, "soften" and "civilize" capitalism. While the market held much promise, it would no longer be left to run its rampant courses, but should be configured to attain that to which society was entitled: some minimum levels of economic well-being. Hence, the market society of the $19^{\text {th }}$ century was transformed into a new prosperous society. ${ }^{15}$ The internationalism and market capitalism of the $19^{\text {th }}$ century was transformed into the nationalism and interventionism of the $20^{\text {th }}$ century. According to Ruggie (1983) and Polanyi (1957), classical liberalism gave way to embedded liberalism: a liberal philosophy embedded in socialist-welfare concerns for growth, employment, and redistribution. The major institutional manifestation of this transformation was the demise of the night-watchman

policy and security policy have reinforced one another). Such was not the case in the $19^{\text {th }}$ century, in which there was a significant disjuncture between the two. While geo-strategic policy was a hot-bed for nationalistic urges, international and domestic economic policies were far less so. This produced scenarios which would be quite unthinkable in the $20^{\text {th }}$ century. For example, Russian bonds continued to be floated on the London market even during the Crimean War (which meant the British were financing the Russian war effort against their own compatriots), and during World War I German ships could purchase war-time catastrophe insurance from Lloyds of London. Similarly, the wave of colonization, according to Cohen (1973) and Fieldhouse (1961), was far more influenced by geo-strategic than economic considerations (i.e., the scramble for colonies was an extension of geo-strategic competition on the Continent). On the disjuncture between economic and geo-strategic policy in the $19^{\text {th }}$ century, see especially Kennedy (1981).

${ }^{14}$ This is not to say that there was no domestic economic policy at all before the $20^{\text {th }}$ century. The state had been active in many ways in domestic and international economic spheres well before the $20^{\text {th }}$ century (poor laws, anti-combination laws, factory laws, bank charter acts, corn laws). A welfare-state apparatus was also visible and growing in the $19^{\text {th }}$ century (especially under Disraeli and Bismarck) with roots in the $16^{\text {th }}$ century Poor Laws. This activity however was far more limited in scope and purpose (more microeconomic than macroeconomic), and it never achieved anything close to the degree of economic interventionism (macroeconomic stabilization) and welfare-provision (social safety programs) of the guardian state of the $20^{\text {th }}$ century. On the early welfare state, see Offe $(1984$, pp. 128,129). See also below. ${ }^{15}$ Hawtrey (1932, p. 300) highlights the Macmillan Report's motor-car analogy as representative of the ideological break with the neoclassical faith in markets during recessionary periods. While a motor-car may run well and be quite useful, it "is not well adapted at pulling itself out of a ditch." 
state and its replacement by the guardian state. The guardian state was a synthesis of the rise of both the welfare state (which provided social safety nets for society) and the interventionist state (state functions and institutions aimed at macroeconomic stabilization for the purpose of maintaining income and employment).

The rudiments of the welfare state extend as far back as the $16^{\text {th }}$ century and the Poor Laws. But these seminal forms of welfare laws were decentralized in administration and based more on punishment than reward. Modern welfare institutions emerged in the $19^{\text {th }}$ century as a result of urbanization and industrialization: the resulting social differentiation and division of labor which resulted created a disparity in living conditions which stimulated a political response. ${ }^{16}$ Scholars who have logged the chronology of the welfare state have cited various phases in its development. Early activity represented government activism that built on Poor Law traditions. Legislation targeted workman's compensation as well as support for sickness and old age. The 1930s saw the rise of fullblown programs oriented around social services and mitigating income insecurity. By the 1950s there was a massive expansion in both programs and coverage, such that now all industrially advanced nations covered the four main social risks: accidents, sickness, unemployment, and old age. Moreover, social insurance schemes became fully integrated according to a comprehensive concept of social welfare. ${ }^{17}$

The interventionist state was far less visible before the turn of the century as macroeconomic stabilization as a systematic policy goal had its roots in the decades just prior to World War I, and macro stabilization based on long-term planning had its roots in the Great Depression of the 1930s. ${ }^{18}$ The interventionist policy orientation was given systematic form, theoretical identity, and intellectual legitimacy by the Keynesian revolution that took hold toward the end of the Great Depression years. With interventionism now fully integrated with a welfare orientation, the guardian state arose as the defender of the poor, the needy (sick, old), and the worker. ${ }^{19}$ The transformation in the functions of the state from the $19^{\text {th }}$ century were captured in Roosevelt's definition of the New Deal: "plain English for a changed concept of the duty and responsibility of government toward economic life." 20

There were a number of processes (critical events, economic ideologies, policy orientations) and actors (subordinate economic classes, politicians reacting to changes in political markets, political parties, unions) that collectively effected the historical transition from market society to the prosperous society. But rather than looking at the causal mechanism as a set of converging factors (i.e., compelling forces that occurred contemporaneously), there is in fact a systematic relation between these processes and

\footnotetext{
${ }^{16}$ The growth of the welfare state in the $19^{\text {th }}$ century was less pronounced because of the ideology of fiscal restraint and asymmetrical political empowerment among classes.

${ }^{17}$ On the rise of the welfare state, see Flora and Alber (1981), Offe (1984), Heclo (1981), and Przeworski (1986).

${ }^{18}$ On the origins of the interventionist policy, see Brinkley (1989), Critchlow and Hawley (1989), Barber (1985), and Franklin Roosevelt (1941, p. 243) and (in Hardman ([1944] 1969, p. 128).

${ }^{19}$ Przeworski (1986) notes that Keynes provided an already vibrant social democratic movement with a policy for managing capitalist economies in a way that preserved the welfare of workers.

${ }^{20}$ Quoted in Barber (1996, p. 19).
} 
actors which represents the precise causal mechanism that explains the historical transition from market society and its night watchman state to the prosperous society and its guardian state. The causal mechanism is driven by class relations and class conflict in modern capitalism. In short, the rise of labor in modern capitalism (in numbers and organization [unions]) was a catalyst for political changes (the political empowerment of subordinate classes [labor and the middle class]). Political empowerment gave these classes the opportunity to translate their own particular ideologies (strongly driven by economic insecurity) into policy (i.e., the guardian state). The new policy orientation was consolidated through compromise with super-ordinate classes that found many desirable qualities in the guardian state. Critical events such as war and depression generated economic and political environments that further compounded this transformation.

Advancing capitalism in the $19^{\text {th }}$ century served to shift the balance of power among classes. Industrialization created a larger labor force, and the larger number was accompanied by greater organization through unions. Modernization made this rising mass more educated, informed, and mobile; hence more demanding and more formidable adversaries for the bourgeoisie. ${ }^{21}$ This growing proletariat began taking on the bourgeoisie on two fronts: direct confrontation in the work environment (the strike and union initiatives) and indirect confrontation (through competition in the political marketplace). ${ }^{22}$ As empowerment through unionization came before actual political empowerment (unionization was well advanced far before the emergence of Leftist parties and the extension of suffrage to subordinate classes), the proletariat resorted more to direct confrontation through the use of strikes and union pressures. However, there was a concurrent (but less pronounced in the $19^{\text {th }}$ century) push to intrude on the political monopoly of the bourgeoisie. The bourgeoisie resisted strongly on both fronts. Direct confrontation became especially pronounced and antagonistic. In fact, unlike competition in political markets, strikes and threats of strikes induced widespread reactions that generated disasters for worker movements throughout the industrialized world in the later- $19^{\text {th }}$ and early $20^{\text {th }}$ centuries. At the micro-level, strikes generated worsened conditions for labor, while at the macro-level they brought forth anti-labor legislation that was devastating to labor and its organization. ${ }^{23}$ This venomous train of direct

\footnotetext{
${ }^{21}$ From the mid- $19^{\text {th }}$ century to World War I there was a considerable increase in the proportion of industrial labor among the adult population. Przeworski (1986, p. 49) attributes a rising proletarian class consciousness in Europe in this period to the convergence of three forces: Marxism and Socialist theory fused with the social movement to galvanize a sense of class (and a militant one at that). In terms of organization, unions effected a shift in the balance of power by giving labor a monopoly power over its supply. In this period, union membership in Europe rose from $9 \%$ of the labor force to $30 \%$. For statistics, see especially Przeworski and Sprague (1986, p 27). On shifts in the class structure generated by advancing capitalism, see Therborn (1977), Rueschemeyer, et. al. (1992), Poggi (1990), Przeworski (1986), Skidelsky (1979), Przeworski and Sprague (1986), and Gough (1979).

${ }^{22}$ I use the terms bourgeoisie and proletariat out of convention, and because the very core of class competition was strongly defined by industrialists and industrial labor. But in reality the class structure of competition was more complex, as privileged (feudal and capitalist) landed classes and agricultural labor were intimately involved in the struggles for political influence and improved working conditions. On the political front, also involved were small and medium farmers, peasants, petty bourgeoisie, and mercantile industrialists. Hence, my usage of these terms reflects a broader conception of the class struggle. On this issue, see especially Rueschemeyer. et. al. (1992), Poggi (1990, p. 91), and Therborn (1977, pp. 24,29).)

${ }^{23}$ The train of large-scale strikes and repressive responses left a long bloody trail in this period: especially visible cases occurred in Belgium $(1886,1891,1902)$ and Sweden (1909). In Britain, there was a long trail
} 
confrontation brought on crisis consequences for both classes (seeds of revolution that threatened institutions of private property, national strikes, antagonistic legislation). According to Polanyi (1957, pp. 234-35) and Gough (1979, p. 66), the class struggle took on an "ominous character." This caused the struggle itself in great part to shift to the political arena where class conflict was muted through the political process. In Przeworski's (1986, p. 11) terminology, the proletariat's insurrection was transformed into a "bloodless" one through political institutions.

Union strikes giving way to political parties and suffrage ("paper stones") in this period marked a transformation in the class struggle. ${ }^{24}$ The link between democratization and union activity comes in more than timing as in a great many cases the political empowerment of labor through parliamentary government and suffrage came as a direct result of labor mobilization. Mobilization was directly responsible for the extension of suffrage in Belgium, Sweden, Austria, Finland, Norway, and Sweden. In Finland and Denmark, mobilization was crucial in bringing about parliamentary government. ${ }^{25}$ According to Rueschemeyer, et. al. (1992, p. 98), extended suffrage and parliamentary government were, in fact, the two major political goals of the European labor movement before the War. Hence, since labor was a catalyst for the extension of suffrage and parliamentary government, democratization in advanced industrial nations featured an extremely strong proletarian element. ${ }^{26}$

That the struggle could shift to the less antagonistic track brought advantages for both groups, which explains the shift. For the proletariat it was the path of least resistance. Mass strikes and the threat of political revolution was disruptive of business and threatened the very market institutions upon which business was founded. Shifting to a more neutral playing field and directing the contest toward trade-union reforms and social relief kept the system of industrial organization in tact. ${ }^{27}$ For the bourgeoisie, the

of conflict between government and unions. The Taft-Vale Case in 1901 established that striking unions could have their financial assets seized. See Przeworski (1986, 12) and Therborn (1977, p. 12.

24 The term comes from Przeworski and Sprague (1986). The timing of the formation of the first Socialist parties and universal male suffrage attest to the shift in revolutionary methods: Belgium (1885 and 1894 respectively), Finland (1899, 1906), Italy (1892, 1913), Netherlands (1878, 1917), Norway $(1887,1898)$ Sweden (1889, 1907), Great Britain (1893, 1918), Austria (1889, 1907), and Spain (1879, 1907). See Przeworski and Sprague (1986, p. 36).

${ }^{25}$ Rueschemeyer, et. al. (1992, p. 96) sees democratic institutions in both France and Britain as delayed responses to labor agitation. In the British case, Taft-Vale appeared to be a watershed as repressive legislation turned the British labor movement toward the political arena. Similarly, in Belgium, after the failure of six general strikes, the Worker's Party sought a greater political alliance with the Catholic Party. In Britain both the Tory and Liberal support of universal male suffrage emanated from competition over the labor vote. See Therborn (1977, 12-23) and Rueschemeyer, et. al. (1992, pp. 92- 96).

${ }^{26}$ In contrast to conventional pluralist and bourgeoisie-led theories of democratization, Therborn (1977) and Rueschemeyer, et. al. (1992) see labor as the protagonist in this process rather than the bourgeoisie or middle classes. This view is supported by the timing and uneven nature of democratization. In all nations, capitalism preceded democratization. Furthermore, in the pattern of extending suffrage, class factors were more compelling than gender and race (women and racial minorities were the last to gain the vote).

27 Also reflective of this shift was an increasing contemporaneous shift in union activity toward tradeunion reforms and away from insurrection. In Russia, this shift was the focal point of Lenin's diatribes in What is to be Done? ([1902] 1986). Gough (1979, p. 62) underscores the growing bourgeois 
political battlefield provided a means of diffusing and moderating the revolutionary fervor of proletarian reform by bringing the contest out of what Jessop (1982, p. 91) calls "collective confrontation." The political process introduced various restraints for the proletarian movement. First, the political game caused a "deradicalization" of political ideology, as the need to gain large voter support (as workers were far short of majorities in all nations) served to water down what originated as a radical agenda oriented around changing the work relationship. This made the political platforms, by nature, more amorphous. This in turn served to dissolve the collective identity of the workers' movement and replaced it with an agenda representative of a broader and less homogenous cross-section of society. ${ }^{28}$ Aside from the dilution of a workers' platform, the larger political alliance caused collective action problems in marshaling demands. Second, like electoral competition, the process of coalition-building in the parliamentary game served to confirm the institutions of capitalism and dilute the class identity of the contest between economic groups. For example, in order to gain the favor of the highly courted agricultural groups, it was necessary to support the institution of private property. Moreover, while parties were often able to preserve some class identity, the coalitions among these parties produced platforms that were quite amorphous. The coalition structure also gave bourgeois groups both veto power over coalition platforms as well as the means of co-opting the labor movement by making trade-offs in setting political priorities. ${ }^{29}$ Finally, the professionalization of party politics further diluted the class ideology of political movements by creating a cadre of political leaders who found that bureaucratic maneuvering was superior to class doctrines for "getting things done." ${ }^{30}$ In effect, the political process served to dilute class cleavages because it transformed the contest from competition between diametrically opposed doctrines to competition among amorphous political agendas which in fact tended to exhibit various points of convergence, as median-voter theory would predict.

Before World War I, the need for political support to effect national unification and destroy the last institutional remnants of feudalism made subordinate classes valuable allies to the prevailing ruling regimes. The War itself further increased their importance, hence led to even greater political empowerment. ${ }^{31}$ The War made ruling regimes dependent on mass mobilization (in terms of military needs and home production) and on popular support. The rising political empowerment generated by

acknowledgement that small losses (reforms) could be compensated by increased worker productivity. See also Therborn (1977, pp. 24,25), Skidelsky (1979, p. 30), and Offe (1984, p. 179).

${ }^{28}$ Przeworski and Sprague (1986, p. p. 55) refer to this as the "dilemma of electoral socialism." Jessop (1990, p. 179) notes how in the political arena bargaining shifted away from fundatmental issues of private property and relations in the workplace. Kloppenberg (1986, p. 200) describes it as a shift from "doctrine" to "process." Voting patterns confirmed this deradicalization process as 1/4 to 1/3 of workers in Europe consistently voted for non-Left parties, and sizable numbers of non-workers voted Left. On this dilemma, see also Offe (1984, pp. 185-87), Jessop (1990, pp. 183-89), and Przeworski (1986, pp. 178-84).

${ }^{29}$ Jessop (1990, p. 176), Offe (1984, p. 185), and Przeworski and Sprague (1986, pp. 42-52) underscore the strategic political advantage enjoyed by the bourgeoisie under the coalition structure.

${ }^{30}$ Heclo (1975), Przeworski and Sprague (1986, pp. 15-17), and Kloppenberg (1986, p. 263) see the political successes of the socialist movement grounded in incremental-bureaucratic ("chisel"), rather than revolutionary ("dynamite"), methods.

${ }^{31}$ Barber (1985, p. 2) notes governments' need to maintain "cooperation" and "understanding" between themselves and industry to promote a stable economic transition out of war. 
dependence was compounded by the effects of the War on postwar politics: as Conservative politics were blamed for the War, and therefore lost much legitimacy. ${ }^{32}$ With the interwar period came a fuller political integration and consolidation of proletarian politics into a more encompassing coalition of lower and middle classes. Where early ventures of the movement into party politics resulted in small pockets of support as a result of a more restricted revolutionary agenda, the post-war movement became all-encompassing as its ongoing quest for political support caused it to appeal to a variety of groups among subordinate classes. It was in this broad consolidation that the mature welfare state was born (i.e., as opposed to the earlier $19^{\text {th }}$ century variant). This was the simple result of the working of political markets under the new balance of power in party politics. Leftist agendas were growing in popularity as a result of the War and the diversification of platforms aimed at the median voter (a natural function of Leftists courting allies). In order to keep up, parties formerly grounded in non-Left agendas were forced to diversify somewhat in that direction. Hence, both Left and Right moved more toward the middle of the political continuum. This also allowed winning coalitions in the parliamentary game, as platforms could be better reconciled, hence maximizing alliance possibilities. ${ }^{33}$ Many points of convergence across politics were essentially grounded in the infrastructure of the welfare state: an intricate network of social support for the worker, the needy, and the middle class in general. ${ }^{34}$

The state would substitute for industrialists in providing acceptable economic conditions for subordinate classes. This was evident in the fact that all the goals of union initiatives of the $19^{\text {th }}$ century became principal legislative targets for Leftist parties in the political arena: minimum pay standards, regulations on working conditions, advancing retirement age, job security (the state as an employer), unemployment and health benefits, retirement stipends, and maximum work hours. ${ }^{35}$ What in the $19^{\text {th }}$ century was

\footnotetext{
${ }^{32}$ Rueschemeyer, et. al. (1992, p. 91). In various nations the political impact was immediate, as suffrage was extended and Leftist parties took power. See Therborn (1977, pp. 21,29).

${ }^{33}$ Representative of this diversification was the rise of reformist Liberalism: what originally emanated from a pro-market (bourgeois) doctrine was tempered by socialist concerns to produce a more politically appealing agenda. The natural alliance with socialists which resulted produced the progressive movement in capitalist nations. Kloppenberg (1986, Ch 8) notes that the dual goals of "efficiency" and "social consciousness" characterized a "new liberalism" that consolidated subordinate groups and bridged the class struggle between the bourgeoisie and these groups. For statistics on the rise of Leftist parties, see Przeworski (1986, p. 18).

${ }^{34}$ A welfare ideology was a natural ideological point of convergence for subordinate groups (hence politically viable as a catalyst for alliance) as they were all in one way or another in precarious economic situations under capitalism (because of work, age, health, income), hence a philosophy espousing the construction of social safety nets was generally appealing. Just prior to World War I Michels observed how the expanded platform had turned labor parties into parties "of the people" [quoted in Przeworski (1986, p. 26)]. For bourgeois groups it meant allies in the political contest and the preservation of market institutions. Offe (1984, p. 184), Gough (1979, p. 67), and Kloppenberg (1986, p. 254) see the welfare state as the institutional manifestation of the political compromise between competing classes which took the form of social democracy. This view is representative of theories which posit the state as a set of institutions devoted to reorienting the class struggle in a way that preserves market economies. See Jessop (1990), Holloway and Picciotto (1978), Poulantzas (1968), and Alford and Friedland (1985).

${ }^{35}$ Rosa Luxemburg was correct in noting that "the division between political and economic struggle...is but an artificial product" [quoted in Przeworski (1986, p. 13)]. Indeed, organized labor remained perhaps the single most dynamic force animating Leftist parties even after the parties evolved into broader social democratic alliances. See Gough (1979, p. 61), Poggi (1990, p. 113), and Jessop (1990, p. 176).
} 
sought directly from industrialists through unions, was in the $20^{\text {th }}$ century transformed to demands from broad-based political alliances directed toward the state, hence it is no surprise that the welfare state carried a proletarian imprint throughout. ${ }^{36}$ In fact, losing this battle in the political arena was preferable for bourgeois groups as the state relieved them of having to directly provide many of these benefits to aggrieved groups. Moreover, the aggrieved groups carried the major burden of their own support through taxes.

The rise of the welfare state was only part of the equation that led to the guardian state, as the guardian state was a synthesis of two policy orientations: 1) providing socialsafety nets (the welfare state) and 2) macroeconomic stabilization (i.e., the interventionist state). While the first was well under way before the War, but was indeed consolidated by the War and the economic troubles of the interwar period, it was certainly these factors that led to the creation of the interventionist state, especially the economic hard times after WWI. The War and economic turbulence of the 1920s served to consolidate an interventionist policy orientation that was germinating in the Progressive period before the War. ${ }^{37}$ In fact, in would not be erroneous to say that economic policy began taking on a Keynesian orientation well before the Keynesian intellectual revolution was set off by the publication of the General Theory in $1936 .{ }^{38}$ The economic impact of demilitarization (employment, reorienting production) and the economic swings in the early 1920s compounded the Progressive quest for economic performance by introducing critical (if not crisis) conditions. The responses were pervasive and fairly uniform, while

\footnotetext{
${ }^{36}$ The pork-barrel of the welfare state carried ample benefits for the proletariat's allies as well: agricultural support programs; public services; and relief for the poor, sick, and old. According to Offe (1984, p. 148) it was this "multifunctional" nature that made the welfare state so politically compelling. Poulantzas (1968), Rueschemeyer et. al., (1992, p. 8), and Przeworski (1986, p. 69) locate the rise of a middle-class consciousness from this ideological synthesis embodied in the welfare state.

${ }^{37}$ The idea of macro stabilization was visible in the two decades before the War . It emanated from the Progressive-period belief that markets could malfunction and therefore required the state to intervene in order to "tame" the capitlaist system. See Brinkley (1989), Barber (1985), and Critchlow and Hawley (1989). Franklin Roosevelt (1941, p. 243) and (in Hardman [1944] 1969, p. 128) went as far as to claim the idea that "government strives to... help our free enterprise system to function" was an American tradition "from our earliest days."

${ }^{38}$ Barber (1985, p. 41) notes that the policy orientation of the 1920s "anticipated most of Keynes's conclusions." However, in this anticipatory Keynesianism nations converged more on general goals and philosophies than on precise structures of macroeconomic policy tools and their uses. Nations did agree on the importance of a macroeconomic orientation for policy, and that policy above all should maintain income, employment, and smooth the business cycle. They also agreed that the state should intervene with effective policy tools to bring these goals about, and that for many nations the principal tool was government spending. There was, however, much less agreement on the precise recipe for stabilization (balanced versus unbalanced budgets, taxation versus inflation, the precise targets of fiscal stimulus, etc). Hence, references to this early Keynesian state signify broader policy outlines and goals.
}

To some extent, this Keynesian posture (fiscal stimulus to maintain employment and income) emerged by default. FDR (in Hardman [1944] 1969, pp. 89-93) himself averred that the state was the only economic catalyst capable of bringing an economy out of depression: it had access to unlimited resources and could not fail as an economic entity. In fact, in late-developers such as Germany, Italy, and Japan there was a long legacy of relying on the state as an economic actor to facilitate industrialization. See Gerschenkron (1943). Indeed, Leon Keyserling was probably correct in stating that the policy responses to the depression years of the interwar period would not have been very different had Keynes not lived at all. See Sandilands (1990, pp. 84,85). 
the timing conformed to specific imperatives across nations: the state stepped forward as an economic champion to maintain income and employment in the face significant obstacles. For the nations that had a legacy of state action (late developers), state intervention to assure macroeconomic performance during the 1920s was a "non-issue." 39 For others, it involved the growth of an institutional infrastructure that laid the groundwork for the Keynesian policy responses to the Great Depression of the 1930s. ${ }^{40}$ Alvin Hansen (1927, p. 205), an astute observer of the times and destined to become one of FDR's most influential academic New Dealers, noted that by the end of the 1920s a definitive macroeconomic posture oriented around the state stepping in to tame the "violent oscillations of the business cycle" had emerged, and consequently "laissez faire [was] being displaced by purposeful and scientific control."

The Great Depression of the 1930s strongly reinforced the macroeconomic interventionist posture of the state in capitalist nations through both its length and severity. The motivation to guard income and employment was heightened by the possibility of deep-secular stagnation in the economy. Even before the publication of General Theory, policy practices were converging onto a mix that was consistent with Keynesian guidelines: government oversight of investment, manpower policies, public works programs, deficit-financed pump priming, and an extension of the welfare state. In terms of economic philosophy, the state needed to be especially active because unemployment could be both severe and prolonged (i.e., Keynes's idea of secular stagnation became compelling among policymakers). ${ }^{41}$ It was the acceptance of this philosophy that turned 1920s-brand of interventionism (more ad hoc and short term in focus) into a 1930s policy style that was more systematic and founded on long-term planning. Indeed the state now had a permanent task. As FDR (1941, p. 32) put it, a "major principle that public funds for public works should be used... [to reduce] unemployment has now been accepted." 42 Probably the greatest contribution of the Keynesian revolution in economic theory was not so much in introducing policy styles for national leaders, but to give already existing practices the academic blessing and legitimation of a systematic and well-respected scientific theory of the macroeconomy.

While the welfare state was a direct creation of the evolution of class relations and their political manifestations, the pervasiveness of the interventionist style was strongly dependent on those processes as well. Like the welfare state, the interventionist state proved a point of compromise in the class and political competition of the period. In terms of class, the interventionist orientation overcame class cleavages by shifting the competition over economic security from a zero-sum game (wages and job security could

\footnotetext{
${ }^{39}$ See Barber (1985, pp. 16-21) and Hall (1989) on the pervasiveness of interventionist policy.

${ }^{40}$ For the U.S. it can be said, in contrast to FDR's (in Hardman [1944] 1969, p. 103) claim that the governments of the 1920s were "do nothing," that the New Deal originated in The President's Council on Unemployment in 1921. Formed by then Secretary of Commerce Herbert Hoover in response to the economic slump of the post-war years, the Council concluded that fiscal policies based on public works were the key to dealing with fluctuations in income and employment. See Barber (1985, p. 16).

${ }^{41}$ On the specific policy mixes of individual nations, see Gourevitch (1989), Przeworski (1986, p. 213), Katzenstein (1985), Barber (1985), and the various contributions in Hall (1989).

42 Alvin Hansen (1947, p. 16) reiterated FDR's observation, nations must "undertake as a primary responsibility the maintenance at all times of adequate employment opportunities." Italics added.
} 
only come at the expense of profits) to a positive-sum game (wages, employment, investment, and profits all depended on the same policy tools of macroeconomic stabilization). In the words of Hirsch, the interventionist state "promised full employment and JS Mill too." 43 According to Gourevitch (1989), the Great Depression further consolidated this class compromise by forming a natural alliance between agriculture, workers, and the bourgeoisie. In terms of politics, interventionism was consistent with the ideologies of all major interwar philosophies. For both the Left (Socialists, Communists) and the Right (Fascists), it attributed to the state the familiar role of economic catalyst for prosperity. For those who wanted progress without having to destroy democracy (Fascists destroyed democracy) or capitalism (as the far Left did), a Keynesian philosophy of social democracy gave them an acceptable means of preserving both. Hence, it appealed across the political continuum: Left, Middle, and Right. ${ }^{44}$

World War II revived the familiar problems of the economic impact of demilitarization, but now the belief in secular stagnation was strong as a result of memories of the Great Depression. The 1940s and 1950s fully consolidated the interventionist state by taking the systematic practices of the 1930s and turning them into law. This period produced the groundwork for legislation and institutions that officially put the state into the permanent business of macroeconomic stabilization (and it exhibited a strong Keynesian fabric): the White Paper on Employment Policy in Great Britain, the Employment Act in the U.S., the Economic Planning Agency in Japan, the Paper on Employment and Income in Canada, the Postwar Economic Planning Commission in Sweden, and the Paper on Full Employment in Australia. ${ }^{45}$ With the consequent wave of legislation and permanent institutions, the interventionist state graduated to the level of the welfare state and together consolidated a fully developed guardian state in advanced capitalist nations. ${ }^{46}$

The shadow cast by the new ideology of prosperity and its guardian state spread to more than state institutions and the legal fabric of nations, it cast an intellectual shadow as well. The emergence of growth theory and business cycles as central issues in the study of economics, as well as the growth of national income accounting and macroeconomic statistics, were also manifestations of the prosperous society. ${ }^{47}$ In terms of statistics, broad measures of economic activity (i.e., macroeconomic statistics) barely existed before World War I. ${ }^{48}$ Both the War and the turbulent economic conditions of the interwar years encouraged the growth of an interventionist policy orientation, which in turn required reliable statistics in order to operationalize performance and stabilization goals. The interwar years consequently marked a revolutionary period in the birth of broad measures of economic activity. One of the first initiatives in this direction was the

\footnotetext{
${ }^{43}$ Quoted in Skidelsky (1979, p. 34). On the interventionist state as a class compromise in the quest for economic security, see also Przeworski (1986, p. 208) and Offe (1984, p. 193).

${ }^{44}$ On the political appeal of Keynesianism, see Skidelsky (1979) and Przeworski (1986, p. 36).

${ }^{45}$ On the wave of legislation and institutions, see Hansen (1947, p. 16).

${ }^{46}$ The entire institutional infrastructure created by the guardian state's programs and bureaucracies represented the major component in the growth of government. On the institutional manifestations of the guardian state, see Brinkley (1989).

${ }^{47}$ See especially Kuznets (1965) on growth theory.

${ }^{48}$ On early ventures into measuring economic activity, see O’Brien (1994).
} 
creation, under Secretary of Commerce Hoover, of the Advisory Committee on Statistics in the U.S. shortly after WWI. The goal of the Committee reflected the "new era" philosophy of economic engineering and prosperity. In Hoover's own words, statistics were required for us to "develop a method by which we may make cumulative progress in social organization." 49 Their efforts launched the monthly publication of the Survey of Business Statistics in 1921. The early 1920s marked a fertile period in the generating economic statistics. The NBER's first task in 1920 was to produce a series of national income statistics. In 1921 Alvin Hansen published his Cycles of Prosperity and Depression. In 1922 the NBER published its Income in the U.S. 1909-1918. The Federal Trade Commission did its pioneering study on income and wealth in the U.S. in 1923.

The hard times of the 1930s fueled this rise in economic measurement. In the U.S., government-affiliated and sponsored measurement initiatives were still driven by Hooverites and other devout statisticians who together formed a dynamic and productive corps of pioneers: Kuznets, Mitchell, Warburton, Hansen, and Currie. These individuals had some renowned counterparts in Britain: Hicks, Stone, Meade, Pigou, and Clark. In this period the NBER, the Division of Economic Research (Commerce Department), the Bureau of the Budget, and the Federal Reserve all pushed the fold of statistical research. While Keynes himself did not produce significant amounts of new measures of the macroeconomy, his work imparted a indelible imprint economic measurement both in the period and after. Keynes provided a systematic theory of the macroeconomy that lent itself to measurement. Kuznets and Warburton's famous estimates of GNP by types of expenditures was inspired by Keynesian theory. Keynesian theory also inspired Lauchlin Currie to make estimates of government's contribution to GNP, as well as Milton Gilbert's contributions to income estimation which left an influential imprint on national income accounting in the U.S. In Britain, the pioneering work of Meade and Stone was done under the advice of Keynes himself. ${ }^{50}$

Growth theory too was driven by considerations of economic performance from its earliest manifestations. The classical growth theory of the $19^{\text {th }}$ century (based in the work of Ricardo, Smith, and Malthus) was stimulated by progress (i.e., the industrial revolution). Like economic measurement, the roots of modern growth theory were formed in the ashes of war and the hard times of the interwar period. The Keynesian revolution further inspired the pioneers of modern growth theory by producing a systematic conception of the macroeconomy with growth as its focal point. Arthur Burns, in fact, locates both the motivations and theoretical foundations of growth theory in the General Theory itself. Evsey Domar and Roy Harrod's pioneering contributions to growth theory took on the task of working out Keynes's theoretical implication of full employment and growth paths (something Keynes himself did not fully do). The growing influence of the secular stagnation thesis, both because of the events of the 1930s and Keynesian revolution, enhanced the importance of analyzing economic growth, as

\footnotetext{
${ }^{49}$ Quoted in Barber (1985, pp. 2,3). Alvin Hansen (1927, p. 205) too voiced a common association between economic intervention and measurement, "modern means of gaining information...make for better insight into and control over economic conditions." Keynes, even well before the historic publication of General Theory, underscored the need for accurate statistics to help government stabilize the economy. See Barber (1985, p. 40).

${ }^{50}$ On the evolution of national income accounting, see especially O’Brien (1994).
} 
possibilities of prolonged unemployment made the adverse effects of depression severe and possibilities for prosperity more fleeting. In the post-war period, Samuelson, Solow, Meade, and Swan built on the work of the 1930s and 40s in contributing to neoclassical growth theroy. Later, the new macroeconomics of rational expectations (Lucas and Sargent) continued the legacy of growth theory through its interest in growth paths. ${ }^{51}$

The formal analysis of business cycles closely paralleled the rise of growth theory. By the interwar period, conditions themselves had a similar impact on business cycle studies. As Hansen (1938, p. 268) noted "Reading the business cycle has become... a national game, yet a desperately serious one." The work of the NBER, Hansen, Mitchell, Haberler, Schumpeter, Keynes, Frisch, and Tinbergen built a strong foundation for business cycle theory in these years, a tradition that would carry the theory to the very central core of the study of macroeconomics, like growth theory itself. ${ }^{52}$

\section{The New Macroeconomic Landscape Under the Prosperous Society}

Political markets have been instrumental in both creating and perpetuating the guardian state. Industrially advanced democratic states have become guardians of the economy because, due to the political transformation that emanated from the evolution of class relations, political incentives have dictated such a role. The political transformation created many more demanders of prosperity in the $20^{\text {th }}$ century, as compared to the $19^{\text {th }}$ century, because the political systems of industrially advanced nations have increasingly empowered classes which have been more likely to suffer from economic adversity, or upon which the main burden of recession falls. In that the main solutions to this problem of economic security (guardian state institutions) have been constructed in ways that are appealing across class lines (i.e., the great class compromise embodied in the guardian state), such solutions have become pervasive. The supply of government policy, under such conditions, has placed a premium on maintaining prosperity. The new electoral imperative has become economic, and policymakers are either rewarded or punished for their performance on the macroeconomic front. ${ }^{53}$

Consequently, industrially advanced democratic states in the $20^{\text {th }}$ century have come to politically monopolize the principal levers of the macroeconomy: the money supply and government spending. Central banks have become truly public institutions,

\footnotetext{
${ }^{51}$ On the evolution of growth theory, see Kuznets (1965) and Scott (1989).

52 On business cycle theory, see Zarnowitz (1992).

${ }^{53}$ As Poggi (1990, p. 139) notes, in the post-war period "the political process has come to revolve chiefly around economic issues." Political platforms across parties have converged around the fundamental points that 1) industrial growth is the dominant social goal and 2) parties rate themselves based on how well they perform in providing such growth. A large literature citing the increased sensitivity of politicians to economic performance in the $20^{\text {th }}$ century has emerged. The literature exhibits a prevailing consensus that the demands for prosperity on the part of voters has fundamentally shaped macroeconomic policy. For surveys, see Mueller (1989) and (1997).
} 
stripped of the profit motive so prevalent during the $19^{\text {th }}$ century. ${ }^{54}$ And while central money management is theoretically designated as independent or semi-independent from politics, the banks themselves serve very public functions. With respect to the government budget, while spending was always subject to government control, it has become far more politicized. The budget in the $19^{\text {th }}$ century was run by much more mechanistic rules embedded in a strict accounting orientation. Both major institutional changes have laid the groundwork for the emergence of a fully developed macroeconomic policy. While the market ideology of the $19^{\text {th }}$ century discouraged the need for macroeconomic policy, the ideology of prosperity of the $20^{\text {th }}$ century has demanded such a policy as the centerpiece of a general economic strategy for the guardian state. The impact of the ideology of prosperity on the macroeconomic landscape is quite evident when we look at both the instruments and principal macroeconomic goals of the guardian state. Through the agency of the guardian state, the ideology has encouraged a new landscape from that which we saw in the $19^{\text {th }}$ century, one characterized by increased prosperity (greater economic growth and employment), higher inflation, and bigger government.

\section{Inflation}

Ruggie (1983, p. 415) calls inflation "the dominant domestic means of dealing with redistributional strife in advanced capitalist economies." Galbraith (1970, p. 168) regards inflation as "deeply woven in our social fabric" because our motives to fight it conflict with our concern for economic growth and security. In fact, the use of the money supply as a means of fighting recession is deeply rooted in capitalist-democratic politics. While such initiatives (generally led by farmers) achieved less success during the $19^{\text {th }}$ century, there was always far greater agitation for reflationary policies during periods of slow growth. ${ }^{55}$ The Great Depression systematically wore down the hard-money resolve of monetary authorities and placed the money supply along side of government activism as the primary instruments with which to fight recession. Hence, government spending and inflation became centerpieces of a strategy for fighting economic adversity. ${ }^{56}$

\footnotetext{
${ }^{54}$ On the growth of public functions and political concerns of central banks in the interwar period, see Hawtrey (1932) and Traynor (1949).

${ }^{55}$ On growth and inflation, see Gallarotti (1995, pp. 151-160) and Barber (1996, p. 14).

56 While various nations resisted reflation in trying to preserve gold standards, which according to Eichengreen (1992) made the Depression much worse, it became increasingly popular among governments in the 1930s. There emerged a feeling that government was responsible for the money supply (i.e., the advent of public central banking) and that it should use its discretion over money in ways that were consistent with growth and employment. The turn toward inflation seemed to remain sturdy in the face of Keynesian beliefs regarding the role of money in an economy. Since money could matter under certain circumstances, according to Keynesians, inflation could be tolerated if it were managed in some countercyclical way. Hence, while reflation had its critics (Kemmerer warned of the inflationary consequences of politicizing money), it was consistent with both the needs and theories of the times.
}

To say that Keynesians could tolerate some inflation is not to attribute a monetarist orientation to Keynes (that money could be an effective tool for counter-cyclical stabilization policies). While Keynes believed that the money supply could have an effect on growth, it was always contingent on how it interacted with other variables (wages, the supply of goods, effective demand, employment, and the interest rate). Furthermore, Keynes himself was quite outspoken about the deleterious effects of inflation 
The use of the money supply to effect economic goals became entrenched in political repertoires after World War II. A large literature has emerged on the political utility of inflation in democracy. On a whole, the literature underscores the political utility generated by government's monopoly over the money supply in terms of attending to the economic imperatives of democratic societies. And while excessive inflation is unacceptable, at least some inflation itself has become a prevalent macroeconomic tool of governments, as inflation allows governments to attend to important welfare and macroeconomic concerns. States can generate short-term increases in growth and employment via trade-offs on the Phillips curve. ${ }^{57}$ In its impact on short-term growth, inflation can reduce adjustment costs in an economy (i.e., labor is more mobile in an expansion). Inflation can also attend to the needs of important political interest groups. Heavily indebted farmers could be relieved of their real debt burdens. Increasing the money supply would allow enough "lubrication" in the economy to accommodate increased nominal wages on the part of unions, and could even stimulate short-term growth if wages have not increased in the same proportion. Finally, inflation could serve broader economic goals such as increasing a society's access to credit.

Managing the money supply can also generate significant indirect political utility as a means of financing government spending (i.e., monetizing the debt). Since government expenditure is the other major instrument for fulfilling the mandates of the prosperous society, any means which could make such spending less painful would be politically useful. In the short-run, virtually all alternatives to financing government expenditures are more painful politically than inflation. Taxes are fairly rigid because the political costs of raising taxes are onerous. Restraint in spending would mean generating less prosperity. Finally, incurring debt would be seen as a cause of future tax hikes and could slow economic growth through its impact on interest rates. The political costs of monetizing debt are less onerous because they can be pushed off in time through inflationary lags. Moreover, they are less transparent since people cannot prove that inflation in any given time period was the result of monetization in previous periods. ${ }^{58}$

Since democracy generates the most pronounced demands for prosperity, and the money supply can be used to attend to those demands in ways that have limited political costs, democracy generates what Burton (1980) refers to as a natural "demand for

throughout his writings. He ([1936] 1964, p. 269) stressed the dangers of the "great instability in prices", perhaps the greatest being to "make business calculations futile." But Keynes however did see the temptation present in monitizing expenditures. In How to Pay for the War (1940), Keynes argued that one of the greatest challenges of post-war economic adjustment was going to be dealing with the inflationary pressures created by war financing. See Kahn (1972, Chs. 6,7), Barber (1996, pp. 88-95), Buchanan and Wagner (1977, pp. 32,33), and Polanyi (1957, pp. 227-230).

${ }^{57}$ While the relation between employment and inflation is contentious, there is a general sentiment among economists that in the short run it is possible to make some gains in employment by increasing the money supply. Since political horizons are short, short-run economic gains are sufficiently important to engage in such trade-offs.

58 The literature on the politics of inflation is large, but excellent collections on the subject are Lindberg and Maier (1985), Hirsch and Goldthorpe (1977), and Whiteley (1980). On the inflationary impact of government growth, see Buchanan and Wagner (1977), Wagner (1980), and Cameron (1985). 
inflation." The empirical track record on money supplies and inflation among the G-7 suggests that the inflationary legacy in industrialized democratic nations is indeed strong.

\section{Tables 5 and 6 Here}

With very few exceptions, money and inflation growth rates are significantly greater after World War II. In inflation, growth rates are greater in the Bretton Woods and post-Bretton Woods periods then they are under the gold standard by a factor of 3.6 and 7.2 respectively. In money supplies, growth rates in the former two periods are more than double those under the gold standard. In both inflation and money growth, there appears to be greater convergence of rates under the gold standard than periods after 1945.

Of course, inflation itself throughout these years was driven by other important factors as well, and such is the case with all the macroeconomic and institutional measures used in this analysis (see below for a discussion about competing explanations). The Bretton Woods years were characterized by a creeping inflation that was to a large extent a cost-push phenomenon. Furthermore, the higher rates after 1970 were driven largely by the oil shocks and intensification of wage demands in the 1970s and 80s. Moreover, higher growth in the period after 1945 may have fueled inflation in those years relative to the slower-growth years before 1914. However, in terms of growth versus inflation, the increase in inflation between these periods is greater than the increase in growth.

\section{The Size of Government}

If the guardian role empowered the state as an economic agent responsible for managing the business cycle, then surely a major instrument it would use to effect this role came from its power to spend. Unlike the period before World War I, countercyclical deficit spending became a welcomed part of a national macroeconomic environment rather than an evil to be tolerated. The power of the purse, in general, gained greater legitimacy during the Depression, and would spread well beyond the restricted role of counter-cyclical wedge to become an essential means of financing prosperity in national economies. ${ }^{59}$ Buying prosperity has occurred across the major functions of government: humanitarian, the supply of public goods, and economic stabilization. Humanitarian spending has become tied up with creating economic safety nets at the lower rungs of society. This category of spending has seen the biggest growth rates after World War II, as transfers have accounted for a larger proportion of the increase in government expenditures than any other item. ${ }^{60}$ Public goods have contributed to prosperity via the provision of goods and services which would substitute for goods

\footnotetext{
${ }^{59}$ On the Keynesian revolution and the role of government spending, see Galbraith (1970) and Barber (1996).

${ }^{60}$ On the humanitarian dimension of government spending, see Meltzer and Richard (1981), Alt and Crystal (1983, p. 205), and Kohl (1981).
} 
procurable through private purchases. Hence, government has supplied some minimum quality of life which is invariant with respect to incomes. Finally, the stabilization role of government spending has maintained a style of interventionist activism across the business cycle.

While a large literature has emerged on the growth of government, it is clear that a common strand among many of the theories suggests that the increasing size of government is in large part a function of political competition to provide prosperity. ${ }^{61}$ Scholars have talked about the fiscal impact of the expanding support functions of democratic governments. Discussions converge around the issue of meeting ever increasing political demands with limited resources. Buchanan and Wagner $(1977,223)$ aver that budgets have become a manifestation of the "constellation of political forces." Kohl (1981) has talked about the "fiscal overload" endemic to the welfare state, while O'Connor (1973) and Janowitz (1976) have conveyed the same argument in terms of a "fiscal crisis." The greater demands for prosperity have placed greater pressure on government to grow. While buying prosperity is necessary, acquiring the means to pay for it has become increasingly difficult since the resource base of government is built up by impoverishing the private sector to some extent (taxation directly reduces incomes, while debt may raise interest rates and create unemployment). ${ }^{62}$ This suggests a dual tendency in democratic nations toward a growth in government and fiscal deficits.

\section{Tables 7 and 8 Here}

Data on G-7 countries are consistent with this expectation. Every nation exhibits a far bigger government in relation to the size of the economy in the periods after World War II. On average the size of government under Bretton Woods was $2 \frac{1}{2}$ times greater than that under the gold standard, while government growth under the post-Bretton Woods period shows an increase by a factor of 3 . The structure of deficits is also revealing. Average balance under the post-Bretton Woods period shows a deficit of almost $2 \%$ of income, while that under the gold standard was in surplus at $0.1 \%$ of income. In Table 8, figures for deficits show that in the last period, with the exception of Germany and Japan, leading democratic nations came to run consistent and large deficits. As expected, the average of significant deficit years is lowest under the gold standard. But a look at the distribution of national averages in Table 8 is even more revealing. Under the gold standard, everybody (with the exception of Germany) was running fairly infrequent deficits that were large. Under the post-Bretton Woods period, almost everybody (with the exception of Japan and Germany) was running frequent-large deficits. A tendency away from deficits has been replaced by a preponderance of large deficits. It may be a testament to the consolidation of the ideology of prosperity in the post-war period that average deficit years are significantly greater under the 1974-1989 (years of peace and void of a great depression) period than they are during the interwar period (a period marked by economic transition from war and severe depression).

\footnotetext{
${ }^{61}$ For a good survey, see Mueller (1989).

${ }^{62}$ Alt and Crystal (1983, p. 191) note an asymmetrical stabilization tendency on the part of democratic governments. While they must spend substantial amounts in confronting economic crises, political market mechanisms work against their ability to recoup the resources in fair weather periods.
} 
Figures for the period 1946-70, on average, show far less tendency toward deficit vis-à-vis the subsequent period (Tables 7 and 8), and only slightly more than the gold standard period (Table 8). Since the former period represented a highpoint of Keynesian policy, one might expect greater relative tendency toward deficit. This however reflects some difficulties in the deficit-trend measure as a reflection of guardian activity. The period in fact represented a highpoint in welfare spending. However, the period also showed considerably higher economic growth than the other two periods. All things being equal, growth itself has a strong impact on the fiscal balance (high growth encourages surplus, while low growth encourages deficits). High growth generates large revenues for the state, while limiting the fiscal pressures leading to excessive spending (growth diminishes economic distress, which reduces the need for transfers). Hence, inconsistencies in the data may reflect the differential impact of growth. But the fact that the period exhibits higher average tendency for deficit vis-à-vis the gold standard, while concurrently showing considerably higher growth, is consistent with a prosperous society argument. $^{63}$

\section{The Goals: Growth and Employment}

Data on the instruments of the guardian state (inflation and government spending) are consistent with a prosperous society argument. In terms of the goals of the prosperous society, we would look above all at economic growth and employment for similar support. In fact, once the ideology of prosperity became fully consolidated and the guardian state arose to preserve its mandate, growth and employment became the sine qua non of economic security. In Galbraith's (1970, p. 105) words, "the notion that [business cycles] must be allowed to run their course [has become] virtually extinct."

\section{Tables 1-4 Here}

Data on growth suggest that the guardian state has met one of its two principal targets. Per capita growth rates (Table 1) conform to expectations. Under the Bretton Woods period average growth is almost three times greater than average growth under the gold standard. Growth in the period after 1973 is 50\% higher. A comparison of standard deviations suggests the attainment of a corollary goal: smoothing out the business cycle to avoid large swings in growth. ${ }^{64}$ Standard deviations are significantly lower in the periods after 1945. This restructuring of the business cycle is picked up in

\footnotetext{
${ }^{63}$ Other difficulties exist as well. Deficits may in fact be the manifestations of unanticipated distress: relief is required too quickly for expenses to be covered in more conventional ways like incremental shifts in marginal tax rates. Furthermore, they may also be influenced by other factors like access to capital markets. All such factors make the fiscal balance less accurate as a reflection of guardian-state activity. The measure is more useful when all of these mitigating factors can be held constant.

${ }^{64}$ Zarnowitz and Moore (1986) have shown that specifically in the case of the U.S. the amplitude of the cycle has been dampened significantly across the century. Bordo (1993, p. 15) cites the influence of counter-cyclical fiscal and monetary policy in smoothing the cycle.
} 
data comparing the structure of business cycles across the periods (Tables 2-4). It appears a rather drastic alteration of the business cycle has occurred across the past century. The length of expansions is far longer and the length of contractions is shorter after World War II. The average length of an expansion is more than twice as long and the length of contractions is about $40 \%$ shorter. Expansions are longer in every single country, while contractions are shorter in every country except Japan and Germany. Looking at the proportion of expansion to contraction years, the proportion favors expansion by a large amount in every single country. The G-7 average is more than three times greater after 1945 than before 1914.

\section{Table 9 Here}

Unemployment figures (Table 9) suggest that G-7 nations have done far better under Bretton Woods than under the gold standard. Unemployment and the volitility of employment is far lower under Bretton Woods. While unemployment is higher after 1973, the standard deviation is lower. Hence, the latter period has shown greater success at attaining the corollary goal of employment smoothing. Employment figures, however, can be misleading as an indicator of the impact of the ideology of prosperity. First, comparisons of employment are made difficult by the non-availability of data for Japan, Canada, and Italy before 1914. Moreover, since it has been a direct goal of the guardian state to reduce the burden of unemployment (e.g., unemployment insurance, transfer payments), one would expect that employment would become more tolerable. Hence, even a higher unemployment rate would not be entirely contradictory to expectations for outcomes under a guardian state. However, quite consistent with the state's guardian role is the evolution of the state as an employer itself. Changes in the figures on government employment over the past century show a dramatic rise. ${ }^{65}$

Of course, just because macroeconomic outcomes conform to those we would expect under a guardian state, this does not eliminate alternative explanations. Could these same outcomes have been produced purely by economic forces, or even have been produced stochastically? Obviously, ideas and politics were not influencing these outcomes alone. While this article is not reductionist (there is no claim here of a theoretical monopoly over causation), there is strong reason to believe that ideas and politics have been instrumental in shaping the texture of macroeconomies across these periods, and hence should be given significant credit for producing such outcomes. The historical track record in political institutions across these time periods suggests that such outcomes were neither an accident nor solely a result of autonomous economic and stochastic forces. The track record strongly avers that they were generated to a large extent by policy. The political landscape of all these nations was marked by the rise of institutions and laws oriented around regulation, welfare, and stabilization: from the

\footnotetext{
${ }^{65}$ In the five leading western nations, for example, changes in percentage of labor force employed by government from pre-World War I to the 1980s attest to the growth of the guardian functions of the state as a direct employer: for France $7.1 \%$ to $32.6 \%$, for Britain $7.1 \%$ to $31.4 \%$, for the U.S. $1.5 \%$ to $18.3 \%$, for Italy $4.7 \%$ to $24.4 \%$, and for Germany $10.6 \%$ to $25.8 \%$. See Poggi (1990).
} 
transformation of central banking to large-scale transfer programs. ${ }^{66}$ This "Galbraithian assault on the market", as Higgs (1987) would call it, spread the protective web of the guardian state to virtually every important component of the macroeconomies of industrially advanced nations. ${ }^{67}$ And these institutions and laws do not even comprise a full representation of economic intervention. They do not include activities not formally regulated by law such as counter-cyclical management of both money supplies and government spending. Surely such institutions, laws, and activities made a difference. Welfare spending and counter-cyclical macroeconomic policy have become mainstays of economic policy in the west.

Furthermore, while any specific variable or period may be better explained by factors other than the prosperous society, it is difficult to conceive of any factor that does better at accounting for the general texture or landscape of macroeconomics across these periods than the change in economic orientations. ${ }^{68}$ Growth, inflation, and employment may have been influenced more by the oil shocks than by government intervention after 1973. Even if this is the case, the data still support the prosperous society argument in other periods. ${ }^{69}$ In addition, oil shocks do not explain the changing structure of the business cycle across the century. While an endogenous growth model might attribute higher growth and better employment performance in the $20^{\text {th }}$ century to greater developments in human capital or technology, it does not as readily explain the growth of government. ${ }^{70}$ The growth of government, inflation, and and fiscal balance may be explained by institutional theories of the size of government such as Higgs (1987), but such theories do not as readily explain the structure of economic growth. Changes in economic growth may well explain changes in employment and inflation, but do not explain the changes in the growth of government.

Structural stability (i.e., Chow) tests on the series suggest that there has indeed been a profound change in macroeconomies from the period of the gold standard to the present. ${ }^{71}$ The tests look for significant structural breaks in the series between the periods 1880-1913 and 1950-1989. The results show strong evidence that there are significant structural changes in macroeconomic and institutional properties across these two periods.

\section{Table 11 Here}

\footnotetext{
${ }^{66}$ Moreover, the intellectual shadow of prosperity was very visible in the evolution of economic theory (growth and business cycle theory) and the measurement of economic activity.

${ }^{67}$ Burns (1960), and Briggs (1968), Higgs (1987), and Buchanan and Wagner (1977) have noted the importance of institutional changes in industrially advanced nations that have created automatic stabilizers for economies.

${ }^{68}$ It has been the intention of this article only to account for the general landscape, and well acknowledges that trends in any given component macroeconomic or institutional statistic may best be explained by alternative factors.

${ }^{69}$ Because of these types of extraordinary events, I have not used the interwar period as a viable period for comparison, as post-war readjustment and severe depression make it too exceptional a period.

${ }^{70}$ On endogenous growth, see Romer (1990).

${ }^{71}$ For more information on the estimation technique, see Appendix.
} 
The individual series for income, money supply, and inflation show strong support for a structural break. The F-statistics are predominantly significant at the .10 level, with more than half being significant at the .05 level. Only one (Germany for money supply) generates a statistic above the .25 level. Government spending shows some support. The U.S., Britain, and France generate F-statistics below the 10 level, but only two nations (Italy and Japan) generate F-statistics with very high probabilities. Support for employment is low (of course, three nations were not tested due to unavailable data in early years). When aggregating all the series in a vector model of the economy (all the series regressed on real income), very strong support for a structural break emerges. All but two nations generate F-statisitics which are significant at the .05 level, and of the two above the .05 level, Canada generates an F-statistic at the .11 level.

Computations using the binomial theorem suggest overwhelming support for a structural break. The individual series represent 32 independent tests. If the series are purely random, and no strucural breaks exist, then the probability of generating $21 \mathrm{~F}-$ statistics which are significant at the .10 level is .0000000 . In the tests on the aggregated model, the probability of getting 5 out of 7 statistically significant estimates (again, using the .10 level) if no structural break exists is .0000064 .

\section{International Economic Relations Under the Prosperous Society}

The ideology of prosperity has had an impact that transcends national boundaries. It has also left an indelible mark on international economic relations. As is evident from convergence estimates across the statistical tables (see especially Tables $1,5,6,7,10$ ), the international economy has seen greater divergence among major macroeconomic indices. This is to be expected since nations have been cast by the ideology of prosperity into a more nationalistic mode. They have come to be primarily concerned with the economic welfare of their own nations, hence we would expect this to result in some divergence since nations are attending to particularistic economic and political imperatives. ${ }^{72}$ While pundits of globalization and free market economists underscore the rising transnationalism and economic interpenetration of the the post-World War II period as reflective of the advent of a truly integrated and global world economy, if you extend time horizons back to the late $19^{\text {th }}$ century, the present age pales in comparison with what was a truly liberal international economy. ${ }^{73}$ The state was far less involved in trans-

\footnotetext{
${ }^{72}$ Of course, as McKinnon (1988) notes, we would have expected greater convergence under the gold standard since exchange rates were fixed in that period. But while this explains differences between the gold standard and the period after 1973, it does not explain as well the greater convergence under the gold standard vis-a-vis the Bretton Woods period when rates were once again fixed. At a more general level, the fixed exchange rates under the gold standard were maintained because the lack of a guardian state relieved policymakers from the pressure of using switching devices to protect growth and employment. See Gallarotti (1995).

${ }^{73}$ Recently, in Partners in Prosperity (1991, p. 6), a panel of prominent economists has emphasized "the greater economic and financial interdependence of the industrial world." Scholars have continued from the 1970 s to the 1990s to talk about the market threat to national sovereignty and the resulting denationalization of economic relations. See Reich (1990) and Vernon (1971).
} 
border economic flows in the $19^{\text {th }}$ century. People, machines, goods, and money were essentially free to move with minimal monitoring and even fewer impediments. As a result, the level of foreign investment as a proportion of the size of economies achieved heights never again matched. Similarly, growth in trade also set records never again matched. The guardian state has monitored and involved itself in orchestrating flows far more than its night watchman predecessor because such flows affect its potential to provide prosperity. It essentially has risen to the challenge of the market in maintaining its mandate. ${ }^{74}$ Hence, it is a far greater economic presence today than it was 100 years prior.

Globalist doomsayers may be premature in announcing the death of the state, since the political market for prosperity remains compelling. In fact, even the so-called greatest perpetrators of globalization (banks and multinationals) are far more scrutinized and regulated today than they ever have been. ${ }^{75}$ While the post-World War II period has seen the emergence of international regimes that have attempted to better integrate national economies, none of them has been able to dislodge the state in its major economic role as guardian. In fact, in their origins and their evolution they very much carry the imprint of economic nationalism. In the $19^{\text {th }}$ century, the state was hardly an economic player. The $20^{\text {th }}$ century would place it squarely at the very center of economic relations. One might say that with the demise of classical liberalism and the rise of an ideology of prosperity, the global economy was transformed from an international economy to an international political economy. Scrutiny of the track record in the major issues of economic relations across the century (money, trade, foreign direct investment, environment, and North-South relations) bears this out.

In terms of monetary relations, cooperation in the $20^{\text {th }}$ century has been strongly conditioned by factors central to the mandate of the guardian state: the quest to maintain control over money supplies, government spending, and the business cycle. The trail of attempts at monetary regime building in the $20^{\text {th }}$ century has shown no more influential forces on cooperation than these. When regimes failed to materialize, fell apart, or succeeded; these factors were in the inner sanctum of causes accounting for the outcomes. In the interwar period domestic goals fundamentally obstructed attempts at cooperation. Early interwar attempts at Brussels and Genoa showed nations reluctant to broach the subject of government finances (in fact the most important issues of war debts and reparations were kept out of the meetings) and leery about the deflationary impact of resumption. At the World Economic Conference in 1933 successful cooperation required more accommodations among money supplies and fiscal targets then nations were willing to give. The U.S. was especially adamant about avoiding any impediments to reflationary policies. Moreover, nations that enjoyed exchange rates which they felt were conducive to greater growth were reluctant to negotiate new parities. The only regime that came into existence in the period was the Tripartite Agreement: a scheme restricted to preventing

\footnotetext{
74 On the competitive state, see Cerny (1995).

${ }^{75}$ On the resilience of states in the global economy, see especially Kapstein (1996).
} 
competitive depreciation among Britain, France, and the U.S. Its origin can be attributed to the fact that it never pressed nations on the coordination issue. ${ }^{76}$

The birth, illness, and demise of Bretton Woods were principally configured by the guardian state's quest to preserve national prosperity. Its entire adjustment scheme called for limited sacrifices with respect to domestic growth and employment. Adjustment through disabsorption (i.e., deflation) was not an option. But since possibilities for switching were also restricted due to pegging, adjustment was configured around short-term balance-of-payments financing through loans (originally designed to be provided by the IMF, but later actually provided by the U.S.). But even the sanctity of the peg fell to domestic priorities, as fundamental disequilibria in payments could justify a change in parities. Void of a change in parities, it was hoped that more substantial adjustment would magically emerge from chaos. Survival through the 1950s was predicated on large unilateral capital flows from the U.S. to Europe and the fact that Europe was spared the burden of convertibility as it could preserve it precious domestic prosperity behind the safe walls of capital controls. As a fully functioning regime in the 1960s it experienced significant adversity, which was invariably reflective of national choices between preserving parities and domestic economic targets. The long-run foundation of the regime relied on nations, especially the U.S., to accommodate their macroeconomic policies to the dictates of preserving the parties. Nations in general, and the U.S. especially, would make no such accommodations. The dollar's own fate was sealed by American choices to run an independent macroeconomic policy based on the U.S.' own domestic and geo-political priorities. While America's preference for inflation in the 1960s accorded well with the need for liquidity in the international system, it eventually undermined the very standard upon which the regime was build: the dollar's relation to gold. ${ }^{77}$

No international regime was ever constructed in the wake of Bretton Woods. We have remained in a "non-system."78 Nations have made different arrangements based on their domestic priorities. Pegging blocs and regional monetary arrangements have been selected by trade-dependent nations, while others (the U.S. being one) have preferred to continue enjoying the macroeconomic freedom of floating. Europe attempted a miniBretton Woods through the snake and the EMS. However, here, as with Bretton Woods, problems of coordinating macroeconomic policies resulted in a rocky history for these monetary arrangements. Things came to a boiling point in 1992. When freed from the safety of capital controls, parities fell in the wake of major disjunctures in macroeconomic performance. Europe is licking its wounds and moving toward monetary union. ${ }^{79}$ Summitry among the G-7 has emerged as the closest thing to an international monetary regime. But the results have hardly represented a systematic assault on monetary problems. The agenda has been fairly ad hoc, and, like all monetary schemes of the $20^{\text {th }}$ century, has been strongly configured by domestic objectives of maintaining

\footnotetext{
${ }^{76}$ On the interwar period, see Traynor (1949), Clarke (1973), Nurkse (1944), Eichengreen (1992), and Briggs (1968).

${ }^{77}$ Especially insightful analyses of the Bretton Woods regime that consider the impact of domestic factors are Ruggie (1983), James (1996), and Eichengreen (1996).

78 The term comes from Corden (1994).

${ }^{79}$ On European arrangements, see Eichengreen (1996).
} 
discretion over the levers of national macroeconomies. None of the summits have seriously threatened this discretion. At a minimum, this cooperation seeks to limit adverse domestic effects of international economic relations (e.g., an over-valued exchange rate), and at a maximum seeks to transfer the burden of adjustment onto others (effect balance by letting others expand, or encouraging joint intervention to bring about desired exchange rate targets rather than unilateral attempts at those targets through undesirable macroeconomic politics). ${ }^{80}$ In these later iterations of monetary cooperation, the state is as strong a presence, and the ideology of prosperity as strong an influence, as they were in the years immediately after World War I. It appears that the guardian state has produced a set of conditions that has made it difficult for nations to return to a regime like the classical gold standard where exchange rates are fixed void of capital controls.

\section{Table 10 Here}

\section{Graph 1 Here}

Such practices have been the exception in the $20^{\text {th }}$ century, as a glance at Table 10 and Graph 1 attest to. As Bordo (1992/93, p. 10) put it, such systems do not function for long in a prosperous society no matter how organizationally sound: "Pegged exchange rates, capital mobility and policy autonomy just do not mix." It appears that Eichengreen (1994) is correct in saying that in the future nations will be constrained to a choice between floating and full monetary unification. Any intermediate regime that attempts to peg rates in the face of full state sovereignty over macroeconomic outcomes is doomed to failure.

Trade relations in the $20^{\text {th }}$ century have also been strongly conditioned by the imperatives of the guardian state. Interwar relations reflected a breakdown due to economic security concerns stimulated by post-war reconstruction and depression. Regime building after World War II saw an aborted regime (ITO) resulting from American trade politics which were driven by concerns over American economic welfare. The birth of a default regime in GATT produced a rather weak institution vis-a-vis the state. The norms of the GATT allowed a plethora of exceptions to the rule of free trade: escape clauses, allowed trade blocs, adherence to dispute rulings were optional, and poor nations were essentially exempted. The whole choice between a more substantial regime (ITO) and a residual regime which functioned as a weaker variant (GATT) reflected a reluctance on the part of the guardian states to allow free trade flows to interfere with their economic security. Historically, the GATT has had its greatest successes in eliminating the least distortionary barriers to trade. Only over the past several decades has it broached the more substantial barriers to trade which are non-tariff. Yet even today, a plethora of such barriers exist. In fact, within the developed world, there is no nation which even comes close to practicing free trade. The new WTO carries over substantial institutional baggage from the GATT, such that its mandate is already restricted due to the restricted coverage of GATT. While adherence to dispute rulings is now mandatory,

\footnotetext{
${ }^{80}$ On summitry, see Funabashi (1988), Putnam and Bayne (1987), Bergsten and Henning (1996), and Webb (1995).
} 
the WTO still defers to the nation-state by encouraging disputants to negotiate bilaterally before imposing its rulings. It has also adopted GATT's practice of informal consensus, which allows individual nations to enjoy the power of unilateral veto.

With all the institutions and negotiations, trade in the post-World War II period has hardly been able to escape a nationalistic mode. Non-tariff barriers are still pervasive, much trade is managed bilaterally (VERs, OMAs), regional trade arrangements have become the rule rather than the exception, and international institutions still leave much room for national discretion under existing rules. ${ }^{81}$

Foreign direct investment in the $19^{\text {th }}$ century, like money and trade, was very much out of the purview of the state. In the $20^{\text {th }}$ century, however, states have come to involve themselves heavily in the investment game. On one dimension they have used their sovereignty to control multinationals so as to assure greater economic benefits as a host. As a home country, nations have come to support the activities of their multinationals through direct (diplomacy) and indirect (providing military security) means. As Kapstein (1996, p. 368) notes, for the MNC, states are at the same time their "most critical allies" and their "worst enemies." 82 The increasing nationalization of resources very much parallels developments in state-MNC relations in as much as control of resources has involved multinationals. This evolution is most starkly reflected in the case of oil. Control of oil shifted from multinationals (Seven Sisters) to nations (OPEC) as oil-rich nations began to exploit the wealth over which they enjoyed sovereign domain. The organization of the cartel essentially shifted from multinationals to nations, and the maintenance of the cartel has been fundamentally dependent on political cooperation among those nations. Conversely, nations whose economies have been affected by the cartel have made the geo-strategy of oil a crucial part of their diplomacy. ${ }^{83}$ While oil has produced the most successful cartel, it is not because nations have not tried to exploit the wealth potential of other resources. In the case of other resources (coffee, aluminum, bauxite, bananas) there have been historic attempts to form nation-directed cartels, but because of economic and/or political problems they have fallen short of the success of OPEC $^{84}$

In North-South relations states are as involved as ever. In fact, this issue area is by nature highly politicized in that decolonization produced a number of nations that have sought to compete with developed nations for the wealth of the international economic system through cooperation. ${ }^{85}$ Relations between the blocs has historically been inherently political, first being driven by Cold War politics, and then by issues regarding the role of less developed countries in the capitalist global economy. ${ }^{86}$ States have continued very much at center stage in the realm of aid. Less developed states have dealt

\footnotetext{
${ }^{81}$ On the GATT, see Finlayson and Zacher (1981). On modern-day trade relations, see Bhagwati (1991) and Busch and Milner (1994).

82 On state-MNC relations, see Gilpin (1975), Bennett and Sharpe (1979), and Moran (1974). For a history of foreign direct investment, see Lipson (1985).

${ }^{83}$ On OPEC and the politics of oil, see Moran (1981), Ghadar (1977), and Mikdashi (1972).

${ }^{84}$ On failed cartels, see Spero and Hart (1997, pp. 306-12).

${ }^{85}$ On collective movements among LDCs, see Gosovic and Ruggie (1975).

${ }^{86}$ On the politics of North-South relations, see Baldwin (1966) and Marchand (1994).
} 
with private banks, but only after clearing hurdles with the IMF. When these nations found it difficult to service their loans, developed nations stepped in to collectively deal with the debt crises. ${ }^{87}$

While the environment is a fairly new issue (from the 1970s and the Stockholm Conference), the short track record of environmental diplomacy reflects the shadow of the guardian state. The major problems which have confronted environmental diplomacy emanate from nations' concerns about the impact of environmental regulation on domestic prosperity. The trail of grand diplomacy on the environment from Stockholm in 1972 through Rio in 1992 shows that the major initiatives produced by these efforts reflect the general objective that environmental regulation be fully consistent with national economic autonomy and domestic prosperity. The general guiding principles which orient the institutions and declarations (all of which are not binding) of these diplomatic conferences fit squarely into the imperatives of the guardian state: (1) nations should pursue environmental regulation within their own domestic priorities, (2) environmental regulation should not be antithetical to development and growth, and (3) national resources should be conserved and protected. ${ }^{88}$

\section{Conclusions}

This article has sought to provide a political-economic explanation of changes in economic performance and structures across the past century. In speaking about economic processes and relations as occupying a singular underlying economic plate, it has presented an alternative to more restricted studies of these relations and processes that conceive of changes as independent from one another. ${ }^{89}$ It has highlighted the role of economic ideologies, class relations, and political markets in conditioning movements in the plate which houses macroeconomic and international economic outcomes across the late $19^{\text {th }}$ and $20^{\text {th }}$ centuries. These factors have transformed the global economic landscape over the past century. It appears that macroeconomies and international economic relations will never be the same with respect to outcomes that were generated under the late $19^{\text {th }}$ century. The ideology of prosperity has blessed nations with higher growth, greater opportunities for employment, and less poverty. But the ideology has also saddled nations with higher inflation, bigger government, and bigger deficits. In economic relations, the ideology of prosperity has placed the state squarely in the nexus of the international economic game. Hence, our age is one marked by a very different texture in our macroeconomies and international economy in which states compete with markets. Speaking in terms of trajectories, what does the future hold for the world economy? It would appear that as long as the ideology of prosperity holds sway over socieities, the present outcomes will be the rule. Interestingly, democracy itself, while it has been so compatible with liberal capitalism, is very much a breeding ground for the ideology of prosperity and the guardian state. Democracy is a political system which

\footnotetext{
${ }^{87}$ On debt crises, see Frydl and Sobol (1988).

${ }^{88}$ On the conferences, see McCormick (1989) and Haas (1992).

${ }^{89}$ Economists have tended to look at economic changes as autonomous. See, for example, Meltzer and Robinson (1989).
} 
maximizes societies' access to economic policy. To the extent that societies are driven by a desire for economic progress, that access will be used to insure the maintenance of some level of prosperity. Hence, while democracy works in favor of liberalism in one respect (democracies preach liberalism and provide enough freedom to economic actors to practice it), it works against it in another respect (encourages the state to manage markets). In other words, democracy can be a force of economic nationalism. If the current trend stressed by the pundits of globalization continues, and democracy continues to spread outside of the western world, then it appears that the future landscape will conform even more strongly to the current pattern. Globalization will not be of a type that sees markets winning over, and displacing, states. Globalization will unfold within a more nationalistic mode. The future will see the ongoing competition between the market and the state rather than the victory of the market, or even the state for that matter. Democracies will never relinquish their commitment to some form of liberal capitalism because extreme autocracy is far more immizerizing than the adverse outcomes of the business cycle. Liberal capitalism fundamentally accords with the ideology of prosperity. The point is that while the prosperous society looks favorably on free-market capitalism, people will not (like their predecessors of the $19^{\text {th }}$ century) go all the way.

\section{Statistical Appendix}

\section{Data}

Income data for Table 1 represent real GNP per capita for all nations except France and Britain, for which real GDP and real NNP per capita respectively were used. Figures on business cycles for the period 1880-1913 in Tables 2 and 4 were estimated from reference cycles in Thorp (1927, pp. 94,95). Figures on business cycles for the period 1948-1996 in Tables 3 and 4 were estimated from reference cycles provided by the Economic Cycle Research Institute at Columbia University. Inflation is measured in Table 5 using the GNP deflator for all nations. Money supplies (Table 6) are measured as follows: M2 for Germany, Canada, Britain, and the U.S.; M3 for Italy; and M1 for France and Japan. Figures on government size and fiscal balance (Tables 7-8) were estimated using data from central government expenditure, central government revenue, and income series from Mitchell (1992), (1993), and (1995). Unemployment data (Table 9) come from Mitchell (1992), (1993), and (1995); and Liesner (1985). Nominal exchange rates (Table 10 and Graph 1) represent the absolute change in bilateral rates of national currencies against the dollar. Series on income, deflator, money supply, and exchange rates were provided by Michael Bordo. See Bordo (1993) for more information on the series. The source for estimates in Tables 1,5,6,10 was Bordo (1993). Tables 1, 5-10 are presented in the format of Table 1.1 in Bordo (1993). Permission to use data and the format from Table 1.1 in Bordo (1993) was granted by the University of Chicago Press, (C) 1993 by the National Bureau of Economic Research.

Structural Stability Tests 
Structural stability tests on the series (Table 11) were done using a Chow breakpoint test. Tests generated two models corresponding to two different periods (1880-1913 and 1950-1989) for all the series as well as a vector model of each national economy, and compared the structure of the coefficient vector of each model across the periods. The Chow test constructs a model comprising estimates over the entire sample, and then fits the model separately to each sub-sample. The output from the test is made up of an F-statistic and accompanying probability. The F-statistic tests the null hypothesis that the coefficient vector over both sub-samples is constant (i.e., there is no structural break in the model from one period to the next). Models for individual series were generated by regressing the relevant series on a constant and a time trend (normalized to be zero in 1879). Vector models for the economies were generated by regressing income on all other relevant series for the individual countries. Estimates were generated using first differences of the logs of the series. This transformation was chosen to minimize possible biases created by heteroskedasticity and non-stationarities in the series. On Chow tests, see Chow (1960) and Fisher (1970).

\begin{tabular}{|c|c|c|c|c|c|c|c|c|}
\hline & \multicolumn{2}{|c|}{$\begin{array}{l}\text { GOLD STANDARD } \\
1881-1913\end{array}$} & \multicolumn{2}{|c|}{$\begin{array}{l}\text { INTERWAR } \\
\text { 1919-1938 }\end{array}$} & \multicolumn{2}{|c|}{$\begin{array}{l}\text { BRETTON WOODS } \\
1946-1970\end{array}$} & \multicolumn{2}{|c|}{$\begin{array}{l}\text { POST BRETTON } \\
\text { WOODS 1974-1989 }\end{array}$} \\
\hline & Mean & Std Dev & Mean & Std Dev & Mean & Std Dev & Mean & Std Dev \\
\hline United States & 1.8 & 5.0 & 0.2 & 8.1 & 2.0 & 2.8 & 2.1 & 2.7 \\
\hline United Kingdom & 1.1 & 2.4 & 1.2 & 4.5 & 2.1 & 1.8 & 1.5 & 4.2 \\
\hline Germany & 1.7 & 2.9 & 2.6 & 8.5 & 5.0 & 3.3 & 2.2 & 1.9 \\
\hline France & 1.5 & 4.6 & 1.3 & 7.2 & 3.9 & 2.2 & 1.7 & 1.5 \\
\hline Japan & 1.4 & 3.8 & 2.0 & 6.1 & 8.1 & 2.7 & 3.5 & 1.1 \\
\hline Canada & 2.3 & 2.8 & 0.2 & 8.8 & 2.5 & 2.6 & 1.6 & 2.6 \\
\hline Italy & 1.0 & 4.1 & 0.9 & 4.7 & 5.6 & 3.3 & 2.5 & 2.2 \\
\hline Average & $\overline{1.5}$ & 3.7 & $\overline{1.2}$ & $\overline{6.8}$ & $\overline{4.2}$ & 2.7 & 2.2 & 2.3 \\
\hline Convergence (2) & $\overline{0.3}$ & $\overline{0.8}$ & $\overline{0.7}$ & $\overline{\overline{1.5}}$ & $\overline{1.8}$ & $\overline{0.4}$ & $\overline{0.5}$ & $\overline{0.7}$ \\
\hline
\end{tabular}

(1) Mean growth rates represent coefficients from a time trend estimated from a regression of the natural $\log$ of real per capita income on a time trend and constant

(2) Convergence is a measure of the mean of the absolute differences between each country mean and the G-7 average 


\begin{tabular}{|l|c|c|c|c|c|c|c|}
\hline TABLE 2: G-7 STRUCTURE OF BUSINESS CYCLES, 1880-1913 \\
\hline & $\begin{array}{l}\text { Full Phases } \\
\text { Exp }\end{array}$ & $\begin{array}{l}\text { \# } \\
\text { Con }\end{array}$ & $\begin{array}{l}\text { Years in } \\
\text { Exp (1) }\end{array}$ & $\begin{array}{l}\text { Years in } \\
\text { Con (1) }\end{array}$ & $\begin{array}{l}\text { Ave. Years } \\
\text { in Exp (1) }\end{array}$ & $\begin{array}{l}\text { Ave. Years } \\
\text { in Con (1) }\end{array}$ & $\begin{array}{l}\text { Yrs Exp/ } \\
\text { Yrs Con (2) }\end{array}$ \\
\hline & 9 & 9 & 17.37 & 13.16 & 1.93 & 1.46 & 1.43 \\
\hline U.S. & 4 & 4 & 16.66 & 13.99 & 4.17 & 3.50 & 1.29 \\
\hline U.K. & 6 & 6 & 18.66 & 14.99 & 3.11 & 1.25 & 1.19 \\
\hline Germany & 4 & 4 & 17.50 & 14.00 & 4.38 & 3.50 & 1.34 \\
\hline France & 5 & 4 & 11.66 & 7.83 & 2.33 & 1.96 & 1.03 \\
\hline Japan & 4 & 3 & 16.50 & 5.50 & 4.13 & 1.83 & 2.20 \\
\hline Canada & 3 & 2 & 12.66 & 4.30 & 4.22 & 2.15 & 1.09 \\
\hline Italy & & & & & & \\
\hline
\end{tabular}

\begin{tabular}{|c|c|c|c|c|c|c|c|}
\hline Total & 35 & 32 & 111 & 74 & & & \\
\hline Average & 5 & 4.57 & & & 3.17 & 2.31 & 1.36 \\
\hline
\end{tabular}

Exp $=$ Expansion, Con=Contraction

(1) Computes figures only for full phases within period

(2) Estimates based on all years in period

\begin{tabular}{|l|c|c|c|c|c|c|c|}
\hline TABLE & 3: G-7 STRUCTURE OF BUSINESS CYCLES, 1948-1996 \\
\hline & Full Phases & \multicolumn{7}{l|}{} \\
\hline & $\begin{array}{l}\# \\
\text { Exp }\end{array}$ & $\begin{array}{l}\# \\
\text { Con }\end{array}$ & $\begin{array}{l}\text { Years in } \\
\text { Exp (1) }\end{array}$ & $\begin{array}{l}\text { Years in } \\
\text { Con (1) }\end{array}$ & $\begin{array}{l}\text { Ave. Years } \\
\text { in Exp (1) }\end{array}$ & $\begin{array}{l}\text { Ave. Years } \\
\text { in Con (1) }\end{array}$ & $\begin{array}{l}\text { Yrs Exp/ } \\
\text { Yrs Con (2) }\end{array}$ \\
\hline U.S. & 8 & 9 & 35.08 & 7.25 & 4.39 & 0.81 & 5.76 \\
\hline U.K. & 3 & 3 & 35.00 & 4.58 & 11.67 & 1.53 & 4.35 \\
\hline Germany & 3 & 4 & 18.75 & 9.53 & 6.25 & 2.33 & 4.25 \\
\hline France & 4 & 5 & 27.42 & 8.58 & 6.85 & 1.72 & 4.71 \\
\hline Japan & 2 & 2 & 35.17 & 4.75 & 17.58 & 2.38 & 2.97 \\
\hline Canada & 4 & 5 & 32.33 & 6.50 & 8.08 & 1.30 & 6.54 \\
\hline Italy & 4 & 5 & 21.58 & 8.67 & 5.40 & 1.73 & 4.65 \\
\hline
\end{tabular}

\begin{tabular}{||l||c||c||c||c||c||c||}
\hline \hline Total & 28 & 33 & 205 & 50 & & \\
\hline \hline Average & 4 & 4.71 & & & & \\
\hline \hline
\end{tabular}

Exp=Expansion, Con=Contraction

(1) Computes figures only for full phases within period

(2) Estimates based on all years in period 


\begin{tabular}{|c|c|c|c|c|c|c|}
\hline & $\begin{array}{c}\text { Ave Yrs (1) } \\
\text { In Exp } \\
1880-1913\end{array}$ & $\begin{array}{l}\text { Ave Yrs (1) } \\
\text { In Exp } \\
1948-1996\end{array}$ & $\begin{array}{c}\text { Ave Yrs (1) } \\
\text { In Con } \\
1880-1913\end{array}$ & $\begin{array}{l}\text { Ave Yrs (1) } \\
\text { In Con } \\
1948-1996\end{array}$ & $\begin{array}{l}\text { Yrs Exp/ (2) } \\
\text { Yrs Con } \\
1880-1913\end{array}$ & $\begin{array}{l}\text { Yrs Exp/ (2) } \\
\text { Yrs Con } \\
1948-1996\end{array}$ \\
\hline U.S. & 1.93 & 4.39 & 1.46 & 0.81 & 1.43 & 5.76 \\
\hline U.K. & 4.17 & 11.67 & 3.50 & 1.53 & 1.29 & 4.35 \\
\hline Germany & 3.11 & 6.25 & 1.25 & 2.33 & 1.19 & 4.25 \\
\hline France & 4.38 & 6.85 & 3.50 & 1.72 & 1.34 & 4.71 \\
\hline Japan & 2.33 & 17.58 & 1.96 & 2.38 & 1.03 & 2.97 \\
\hline Canada & 4.13 & 8.08 & 1.83 & 1.30 & 2.20 & 6.54 \\
\hline Italy & 4.22 & 5.40 & 2.15 & 1.73 & 1.09 & 4.65 \\
\hline Average & 3.17 & 8.60 & 2.31 & 1.51 & 1.36 & 4.75 \\
\hline
\end{tabular}

(1) Computes figures for only full phases within period

(2) Estimates based on all years in the relevant periods

\begin{tabular}{|c|c|c|c|c|c|c|c|c|}
\hline & \multicolumn{2}{|c|}{$\begin{array}{l}\text { GOLD STANDARD } \\
1881-1913\end{array}$} & \multicolumn{2}{|c|}{$\begin{array}{l}\text { INTERWAR } \\
\text { 1919-1938 }\end{array}$} & \multicolumn{2}{|c|}{$\begin{array}{l}\text { BRETTON WOODS } \\
1946-1970\end{array}$} & \multicolumn{2}{|c|}{$\begin{array}{l}\text { POST BRETTON } \\
\text { WOODS 1974-1989 }\end{array}$} \\
\hline & Mean & Std Dev & Mean & Std Dev & Mean & Std Dev & Mean & Std Dev \\
\hline United States & .3 & 3.1 & -1.8 & 7.6 & 2.4 & 2.6 & 5.6 & 2.4 \\
\hline United Kingdom & .3 & 3.1 & -1.5 & 7.8 & 3.7 & 2.2 & 9.4 & 6.1 \\
\hline Germany & .6 & 2.6 & -2.1 & 4.7 & 2.7 & 4.0 & 3.3 & 1.3 \\
\hline France & .0 & $\overline{5.0}$ & 2.2 & 9.1 & 5.6 & 4.1 & 8.8 & 3.2 \\
\hline Japan & 4.6 & 5.5 & -1.7 & 7.3 & 4.5 & 4.6 & 2.6 & 2.4 \\
\hline Canada & .4 & 1.4 & -1.9 & 6.0 & 2.7 & 3.0 & 7.9 & 3.0 \\
\hline Italy & .6 & 3.2 & -1.1 & 11.7 & 3.8 & 11.5 & 12.9 & 4.6 \\
\hline Average & $\overline{1.0}$ & $\overline{3.4}$ & -1.1 & $\overline{7.7}$ & $\overline{3.6}$ & $\overline{4.6}$ & 7.2 & $\overline{3.3}$ \\
\hline Convergence (2) & $1.0^{* * *}$ & $\overline{1.0}$ & $\overline{1.0}$ & $\overline{1.5}$ & .9 & 2.0 & 2.9 & $\overline{1.2}$ \\
\hline
\end{tabular}

(1) Mean growth rates represent coefficients from a time trend estimated from a regression of the natural log of the GNP deflator on a time trend and constant

(2) Convergence is a measure of the mean of the absolute differences between each country mean and the G-7 average

** .63 without Japan 


\begin{tabular}{|c|c|c|c|c|c|c|c|c|}
\hline & \multicolumn{2}{|c|}{$\begin{array}{l}\text { GOLD STANDARD } \\
1881-1913\end{array}$} & \multicolumn{2}{|c|}{$\begin{array}{l}\text { INTERWAR } \\
\text { 1919-1938 }\end{array}$} & \multicolumn{2}{|c|}{$\begin{array}{l}\text { BRETTON WOODS } \\
1946-1970\end{array}$} & \multicolumn{2}{|c|}{$\begin{array}{l}\text { POST BRETTON } \\
\text { WOODS 1974-1989 }\end{array}$} \\
\hline & Mean & Std Dev & Mean & Std Dev & Mean & Std Dev & Mean & Std Dev \\
\hline United States & 6.1 & 5.9 & 0.6 & 8.6 & 6.3 & 5.8 & 8.6 & 2.4 \\
\hline United Kingdom & 2.1 & 1.7 & 0.8 & 4.7 & 3.2 & 3.2 & 13.5 & 5.6 \\
\hline Germany & 5.7 & 4.7 & 1.3 & 10.1 & 12.8 & 6.0 & 5.7 & 4.5 \\
\hline France & 2.2 & 3.5 & 6.4 & 8.5 & 11.5 & 7.5 & 8.8 & 3.4 \\
\hline Japan & 5.8 & 10.8 & 0.5 & 9.7 & 17.3 & 15.9 & 5.7 & 6.2 \\
\hline Canada & 7.4 & 5.3 & 1.1 & 4.7 & 6.0 & 4.0 & 11.0 & 5.5 \\
\hline Italy & 3.2 & 3.1 & 3.6 & 6.2 & 13.3 & 7.8 & 13.4 & 4.9 \\
\hline Average & 4.6 & $\overline{5.0}$ & 2.0 & 7.5 & $\overline{10.1}$ & 7.2 & 9.5 & $\overline{4.6}$ \\
\hline Convergence (2) & 1.8 & 2.0 & 1.7 & 2.0 & 4.2 & 2.8 & 2.7 & $\overline{1.1}$ \\
\hline
\end{tabular}

(1) Mean growth rates represent coefficients from a time trend estimated from a regression of the natural $\log$ of money supply on a time trend and constant

(2) Convergence is a measure of the mean of the absolute differences between each country mean and the G-7 average

\begin{tabular}{|c|c|c|c|c|c|c|c|c|}
\hline & \multicolumn{2}{|c|}{$\begin{array}{l}\text { GOLD STANDARD } \\
1881-1913\end{array}$} & \multicolumn{2}{|c|}{$\begin{array}{l}\text { INTERWAR } \\
\text { 1919-1938 }\end{array}$} & \multicolumn{2}{|c|}{$\begin{array}{l}\text { BRETTON WOODS } \\
1946-1970\end{array}$} & \multicolumn{2}{|c|}{$\begin{array}{l}\text { POST BRETTON } \\
\text { WOODS 1974-1989 }\end{array}$} \\
\hline & $\begin{array}{c}\text { Gov Exp } \\
\text { as \% } \\
\text { Income }\end{array}$ & $\begin{array}{l}\text { Surp/Def } \\
\text { as \% of } \\
\text { Income (1) }\end{array}$ & $\begin{array}{c}\text { Gov Exp } \\
\text { as \% } \\
\text { Income }\end{array}$ & $\begin{array}{l}\text { Surp/Def } \\
\text { as \% of } \\
\text { Income(1) }\end{array}$ & $\begin{array}{c}\text { Gov Exp as } \\
\% \\
\text { Income }\end{array}$ & $\begin{array}{c}\text { Surp/Def as } \\
\% \text { of } \\
\text { Income }(1)\end{array}$ & $\begin{array}{c}\text { Gov Exp } \\
\text { as \% } \\
\text { Income }\end{array}$ & $\begin{array}{l}\text { Surp/Def } \\
\text { as \% of } \\
\text { Income }(1)\end{array}$ \\
\hline United States & 2.37 & 0.24 & 6.65 & -1.78 & 17.90 & -0.28 & 21.70 & -3.47 \\
\hline United Kingdom & 7.65 & -0.05 & 20.15 & 0.78 & 29.89 & 2.48 & 35.88 & -3.19 \\
\hline Germany & 5.37 & -2.83 & 10.71 & $\begin{array}{l}-1.41 \\
\end{array}$ & 14.30 & 4.53 & 14.50 & 7.06 \\
\hline France & 11.68 & -0.51 & 19.51 & -4.30 & 21.82 & -1.09 & 22.44 & -1.14 \\
\hline Japan & 15.80 & 5.65 & 28.86 & 5.88 & 31.18 & 0.79 & 35.18 & 2.68 \\
\hline Canada & 5.58 & -0.46 & 9.94 & -1.54 & 16.26 & 0.83 & 23.29 & -3.18 \\
\hline Italy & 13.85 & -0.91 & 26.53 & -9.93 & 21.53 & -5.61 & 36.98 & -12.57 \\
\hline Average & 8.90 & 0.10 & $\overline{17.48}$ & -1.76 & 21.84 & 0.24 & 27.14 & -1.97 \\
\hline Convergence (2) & 4.32 & 1.54 & 7.56 & 3.11 & 4.97 & 1.91 & 7.62 & 4.21 \\
\hline
\end{tabular}

Exp= central government expenditure, Surp=fiscal surplus, Def=fiscal deficit

(1) Figures in these columns represent the average yearly fiscal balance as a percentage of national income for the relevant sample period. Negative signs in these columns represent deficits, while positive numbers represent surpluses. 


\begin{tabular}{|c|c|c|c|c|}
\hline & $\begin{array}{l}\text { GOLD STANDARD } \\
1881-1913\end{array}$ & $\begin{array}{l}\text { INTERWAR } \\
\text { 1919-1938 }\end{array}$ & $\begin{array}{l}\text { BRETTON WOODS } \\
1946-1970\end{array}$ & $\begin{array}{l}\text { POST BRETTON } \\
\text { WOODS 1974-1989 }\end{array}$ \\
\hline & $\begin{array}{l}\text { Deficit Yrs/ Yrs in } \\
\text { Sample \% }\end{array}$ & $\begin{array}{l}\text { Deficit Yrs/Yrs in } \\
\text { Sample \% }\end{array}$ & $\begin{array}{l}\text { Deficit Yrs/Yrs in } \\
\text { Sample \% }\end{array}$ & $\begin{array}{l}\text { Deficit Yrs/ Yrs in } \\
\text { Sample \% (1) }\end{array}$ \\
\hline United States & 0 & 40 & 20 & 93 \\
\hline United Kingdom & 12 & 5 & 4 & 87 \\
\hline Germany & 100 & 9 & 5 & 0 \\
\hline France & 21 & 79 & 48 & 47 \\
\hline Japan & 10 & 0 & 12 & 0 \\
\hline Canada & 15 & 55 & 4 & 87 \\
\hline Italy & 30 & 90 & 100 & 100 \\
\hline Average & 26.85 & 39.71 & 27.57 & 59.00 \\
\hline
\end{tabular}

(1) Estimates represent number of years in which fiscal deficits surpassed $1 \%$ of national income divided by total number of observation years in the sample.

\begin{tabular}{|c|c|c|c|c|c|c|c|c|}
\hline & \multicolumn{2}{|c|}{$\begin{array}{l}\text { GOLD STANDARD } \\
1881-1913\end{array}$} & \multicolumn{2}{|c|}{$\begin{array}{l}\text { INTERWAR } \\
1919-1938\end{array}$} & \multicolumn{2}{|c|}{$\begin{array}{l}\text { BRETTON WOODS } \\
1946-1970\end{array}$} & \multicolumn{2}{|c|}{$\begin{array}{l}\text { POST BRETTON } \\
\text { WOODS 1974-1989 }\end{array}$} \\
\hline & Mean & Std Dev & Mean & Std Dev & Mean & Std Dev & Mean & Std Dev \\
\hline United States & 7.06 & 4.5 & 10.66 & 8.1 & 4.61 & 1.1 & 7.13 & 1.3 \\
\hline United Kingdom & 4.42 & 1.9 & 9.28 & 3.4 & 1.80 & 0.4 & 7.31 & 2.9 \\
\hline Germany & 2.37 & 1.6 & 11.32 & 8.2 & 3.78 & 3.1 & 6.13 & 2.8 \\
\hline France & 7.35 & 1.5 & 4.45 & 2.5 & 1.45 & 0.5 & 7.23 & 2.6 \\
\hline Japan & $\mathrm{Na}$ & $\mathrm{Na}$ & 4.79 & 1.2 & 1.15 & 0.3 & 2.28 & 0.4 \\
\hline Canada & $\mathrm{Na}$ & $\mathrm{Na}$ & 8.41 & 5.7 & 4.10 & 1.8 & 8.59 & 1.8 \\
\hline Italy & $\mathrm{Na}$ & $\mathrm{Na}$ & 4.45 & 0.2 & 6.21 & 2.7 & 8.69 & 2.1 \\
\hline Average & 5.30 & $\overline{2.4}$ & 7.62 & 4.2 & 3.30 & 1.4 & 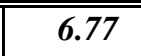 & 2.0 \\
\hline Convergence (1) & 1.9 & 1.1 & 2.6 & 2.7 & $\overline{1.6}$ & 1.0 & 1.4 & 0.8 \\
\hline
\end{tabular}

(1) Convergence is a measure of the mean of the absolute differences between each country mean and the G-7 average 


\begin{tabular}{|c|c|c|c|c|c|c|c|c|}
\hline & \multicolumn{2}{|c|}{$\begin{array}{l}\text { GOLD STANDARD } \\
1881-1913\end{array}$} & \multicolumn{2}{|c|}{$\begin{array}{l}\text { INTERWAR } \\
1919-1938\end{array}$} & \multicolumn{2}{|c|}{$\begin{array}{l}\text { BRETTON WOODS } \\
1946-1970\end{array}$} & \multicolumn{2}{|c|}{$\begin{array}{l}\text { POST BRETTON } \\
\text { WOODS 1974-1989 }\end{array}$} \\
\hline & Mean & Std Dev & Mean & Std Dev & Mean & Std Dev & Mean & Std Dev \\
\hline United Kingdom & .2 & .2 & 6.8 & 7.9 & 2.4 & 6.3 & 10.1 & 4.7 \\
\hline Germany & .2 & .1 & 3.9 & 9.5 & 1.8 & 3.8 & 9.3 & 8.2 \\
\hline France & .3 & .2 & 17.8 & 16.9 & 2.5 & 7.7 & 10.7 & 7.8 \\
\hline Japan & 2.9 & 4.5 & 6.7 & 8.9 & 15.9 & 37.2 & 8.8 & 9.5 \\
\hline Canada & .0 & .0 & 2.6 & 3.4 & 1.6 & 1.9 & 3.7 & 2.4 \\
\hline Italy & 1.4 & 1.5 & 13.6 & 20.1 & 7.4 & 20.6 & 10.9 & 9.0 \\
\hline Average & .8 & 1.1 & 8.6 & 11.1 & 5.27 & 12.92 & 8.9 & 6.9 \\
\hline Convergence (2) & $\bar{~} .9$ & 1.3 & 4.8 & 4.9 & $\overline{4.3}$ & $\overline{10.6}$ & $\overline{1.8}$ & 2.3 \\
\hline
\end{tabular}

(1) Estimates are in absolute rates of change as measured in first differences of the natural log

(2) Convergence is a measure of the mean of the absolute differences between each country mean and the G-7 average

\begin{tabular}{|c|c|c|c|c|c|c|}
\hline & $\begin{array}{c}\text { REAL } \\
\text { INCOME }\end{array}$ & $\begin{array}{l}\text { MONEY } \\
\text { SUPPLY }\end{array}$ & $\begin{array}{c}\text { INFLA } \\
\text { (GNP DEF) }\end{array}$ & $\begin{array}{l}\text { GOV EXP/ } \\
\text { INCOME }\end{array}$ & UNEMP & $\begin{array}{l}\text { MODEL } \\
\text { (2) }\end{array}$ \\
\hline United States & $\begin{array}{l}3.06 \\
(.05)\end{array}$ & $\begin{array}{l}2.78 \\
(.07)\end{array}$ & $\begin{array}{l}3.14 \\
(.05)\end{array}$ & $\begin{array}{l}3.87 \\
(.03)\end{array}$ & $\begin{array}{c}.26 \\
(.77)\end{array}$ & $\begin{array}{l}3.16 \\
(.01)\end{array}$ \\
\hline United Kingdom & $\begin{array}{l}2.69 \\
(.07) \\
\end{array}$ & $\begin{array}{l}1.49 \\
(.23) \\
\end{array}$ & $\begin{array}{l}3.11 \\
(.05) \\
\end{array}$ & $\begin{array}{l}2.66 \\
(.08) \\
\end{array}$ & $\begin{array}{c}.05 \\
(.95) \\
\end{array}$ & $\begin{array}{l}.77 \\
(.60) \\
\end{array}$ \\
\hline Germany & $\begin{array}{l}5.38 \\
(.01) \\
\end{array}$ & $\begin{array}{c}.49 \\
(.61) \\
\end{array}$ & $\begin{array}{l}2.10 \\
(.13) \\
\end{array}$ & $\begin{array}{r}1.60 \\
(.21) \\
\end{array}$ & $\begin{array}{c}.38 \\
(.69) \\
\end{array}$ & $\begin{array}{l}11.09 \\
(.00) \\
\end{array}$ \\
\hline France & $\begin{array}{l}6.79 \\
(.00)\end{array}$ & $\begin{array}{l}4.18 \\
(.02)\end{array}$ & $\begin{array}{l}3.58 \\
(.03)\end{array}$ & $\begin{array}{l}2.67 \\
(.08)\end{array}$ & $\begin{array}{l}2.68 \\
(.08)\end{array}$ & $\begin{array}{l}5.59 \\
(.00)\end{array}$ \\
\hline Japan & $\begin{array}{l}14.58 \\
(.00)\end{array}$ & $\begin{array}{l}9.57 \\
(.00)\end{array}$ & $\begin{array}{l}3.01 \\
(.06)\end{array}$ & $\begin{array}{l}.04 \\
(.96)\end{array}$ & $\mathrm{NA}$ & $\begin{array}{l}5.33 \\
(.00)\end{array}$ \\
\hline Canada & $\begin{array}{l}4.30 \\
(.02)\end{array}$ & $\begin{array}{l}2.05 \\
(.14)\end{array}$ & $\begin{array}{l}2.58 \\
(.08)\end{array}$ & $\begin{array}{l}1.44 \\
(.24)\end{array}$ & NA & $\begin{array}{l}1.88 \\
(.11)\end{array}$ \\
\hline Italy & $\begin{array}{l}9.62 \\
(.00) \\
\end{array}$ & $\begin{array}{l}3.83 \\
(.03) \\
\end{array}$ & $\begin{array}{l}2.86 \\
(.06) \\
\end{array}$ & $\begin{array}{l}.05 \\
(.95) \\
\end{array}$ & NA & $\begin{array}{l}4.48 \\
(.00) \\
\end{array}$ \\
\hline
\end{tabular}

(1) F-statistics are reported along with accompanying probabilities in parentheses. Stability tests were run on models which regressed the relevant series (first differences of logs) on a constant and a time trend. The F-statistics test the null hypothesis that the coefficient vectors from the models are the same across both periods. See Appendix for more information on the stability tests. 
(2) For Japan, Canada, and Italy, the vector model runs stability tests on the following equation: real income $=\mathrm{c}+$ real income $(-1)+$ deflator + money supply + government expenditure/income. For the United States, Britain, Germany and France, the vector model equation is real income $=c+$ real income(-1)+deflator +money supply + government expenditure/income + unemployment. All estimates have been performed in first differences of logs.

Graph 1: G-7 Nominal Exchange Rates (Absolute Change in Nation/U.S. Dollar Rates), 1880-1989
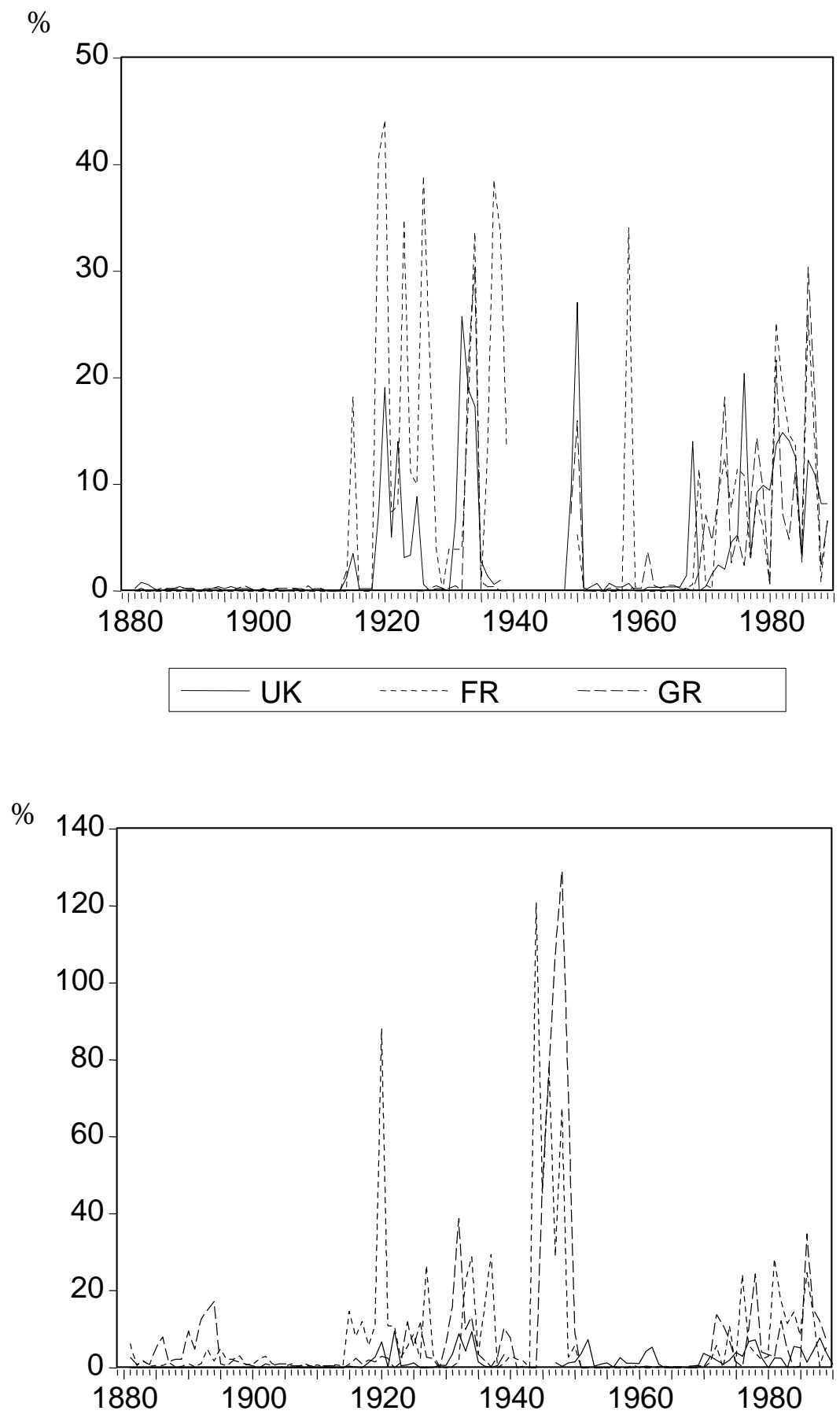

\begin{tabular}{|c|c|c|}
\hline CAN & $\cdots \cdots$ IT & $---J \mathrm{JA}$ \\
\hline
\end{tabular}

